\title{
Antti-Ville Kärjä
}

\section{KILTIT LAPSET EIVÄT MELUA \\ - MUSIIKKIVIDEOISSAKAAN}

Toukokuussa 2009 olin lasteni koulun vanhemmille tarkoitetussa nuorten hyvinvointia koskevassa keskustelutilaisuudessa. Keskustelun pohjana oli STAKESin edellisvuonna 8- ja 9-luokkalaisille tekemä kouluterveyskysely. Keskusteltaessa erilaisista esimerkiksi masentuneisuuteen ja ruokahaluun vaikuttavista huolenaiheista, yksi vanhemmista ei uskonut, että "nää johtus kaikki koulusta vaan näitä tulee [esimerkiksi] meediasta ja musiikkivideoista ja mitä ne kattoo; myös muualta tulee niinku paineita".

Audiovisuaalisen mediakulttuurin painoarvoa elämäntapojen ja jopa -ihanteiden lähteenä ei tulekaan väheksyä. Vaikka nuoret ihmiset osaisivatkin erottaa sepitteelliset tapahtumat ja hahmot todellisista, lihaa ja verta olevat äänelliskuvalliset ihmisesiintyjät viestivät olemuksellaan, asustuksellaan, toiminnallaan ja äänillään erilaisia maailmassaolemisen tapoja. Mikäli tietyt esitystavat toistuvat muita enemmän, on ne helppo ymmärtää laajemminkin yhteiskunnallisesti hyväksyttäviksi tai jopa toivottaviksi. Musiikkivideot ovat myös usein häilyviä sepitteellisyyden suhteen: vaikka videoissa näkisi ja kuulisikin todellisen esiintyjän, ei yleisöllä ole yleensä mahdollisuutta muuta kuin arvailla julkisen tähtipersoonan taustalla olevan yksityishenkilön luonnetta. Lisäksi videot ovat markkinointituotteina aina tietoisia rakennelmia, joissa todellisen esiintyjän eläviä esityksiäkin käsitellään, rajataan ja toistuvasti täydennetään täysin sepitteellisellä kuva-aineksella.

Audiovisuaalinen media ja musiikkivideot sen osana eivät myöskään kiinnity vain teini-ikäisten elämään. Näin nykypäivän rock-, pop-, rap- ja muiden muotimu- 
siikkien ikähaitari vain levenee levenemistään. Yläpäästä voi löytää yhä esiintyvän 66-vuotiaan Mick Jaggerin The Rolling Stones -yhtyeestä sekä "pysyvän jälkensä suomirockin historiaan" jättävän (tai jättäneen) K-70-televisio-ohjelman, jossa yli 70vuotiaista osallistujista koottu kuoro tulkitsee "suomalaisia rock-klassikoita - - uudella tavalla" (MTV3 2009). Toisessa päässä taas ovat esimerkiksi YLEn vuonna 2005 tuottama 3,2,1 - Videox! -sarja sekä MTV3:1la ja SubTV:1lä vuosina 2000-2009 pyörinyt Kids Top20 -ohjelma. Näistä edellinen esitettiiin alkujaan sunnuntain Lasten aamu -ohjelmapaketissa ja se koostuu yhdeksästä 4- ja 5-luokkalaisten tekemästä "musavideosta" (YLE 2005). Jälkimmäinen puolestaan oli nimensä mukaisesti lapsille suunnattu listaohjelma, jonka yksittäiset jaksot kestivät noin 20 minuuttia (KT20 2009).

Tarkasteluni kohdistuu juuri lasten musiikkivideoihin omana diskursiivisena kategorianaan. Tähän on kaksi keskeistä syytä: mediakasvatuksellisten kysymysten ohella ilmiötä voi pohtia suhteessa laajempaan kulttuuri-, media- ja musiikkiteollisen toimintaan. Viime vuosien kiihkeääkin mediakasvatuskeskustelua ajatellen onkin huomionarvoista, että musiikkivideoiden ja lasten (eli käytännössä alle 13-vuotiaiden) suhteeseen ei ole kiinnitetty huomiota oikeastaan ollenkaan. Osaltaan tämä johtunee musiikkivideo- ja populaarimusiikin tutkimuksen nuorisokeskeisyydestä: esimerkiksi tuoreen Medium Cool-kokoelman (Beebe \& Middleton 2007) hakemistossa on vain yksi ikään viittaava hakusana, "youth". Vastaavasti lasten populaarikulttuurin tutkimuksessa musiikilliset ilmiöt ovat jääneet marginaaliin: aiheen mukaan nimetyssä kirjassaan Claudia Mitchell ja Jacqueline Reid-Walsh (2002) käsittelevät kuutta tilaa (engl. space), jotka ovat poliittinen, muistinvarainen, visuaalinen, fyysinen, virtuaalinen ja historiallinen. Tämän perusteella lasten populaarikulttuurissa ei olisi erillistä äänellistä tilaa - vaikka Mitchell ja Reid-Walsh (2002: 5) esimerkiksi huomauttavat siitä, miten joissakin lastenvaatemainoksissa eri aikakausien musiikit ikään kuin sulautuvat kaikkien asiaankuuluvien ikäryhmien (eli niin käyttäjien kuin maksajienkin) yhteiseksi musiikiksi. Tästä huolimatta he eivät kirjoita yksityiskohtaisemmin lainkaan siitä, miten (populaari)musiikki osaltaan vaikuttaa tutkimuksen lähtökohtiin, menneisyyden muistamiseen, nykyisyyden tallentamiseen, lastenhuoneiden järjestykseen, mediaympäristöön tai saman tuotteen (kuten vaikka Barbienuken) muutoksiin ajan kuluessa.

Käsittelen lasten musiikkivideoita diskursiivisten käytäntöjen joukkona ja verkostona eli dispositiivina (Foucault 1998: 39-40), mikä tarkoittaa huomion kiinnittämistä siihen, miten tietynlaiset äänelliset ja kuvalliset esitystavat kietoutuvat yhteen kielellisen merkityksenannon sekä muiden kulttuuristen, sosiaalisten, poliittisten 
ja taloudellisten käytäntöjen kanssa. Dispositiiviajatuksen ytimessä on lisäksi kysymys sosiaalisista valtasuhteista, ja niinpä lähtökohtana ei ole videoiden tason tai laadun arviointi, vaan se, millaisia valta-asetelmia videoiden avulla luodaan, ylläpidetään ja haastetaan eli millaisia "vallan monimuotoisia tekniikoita" (Foucault 1998: 17) niihin liittyy. Lasten musiikkivideot tulevat olevaisiksi sillä hetkellä kun tietyt audiovisuaaliset mediaesitykset yhdistetään tähän termiin (esimerkiksi televisio-ohjelmissa tai verkkosivuilla). Keskeiset kysymykset koskevat tällöin yhtäältä sitä, millaisista äänelliskuvallisista esitystavoista tällaiset musiikkivideot koostuvat, ja toisaalta sitä, miten ja kenen ehdoilla ihmisjoukko nimeltä lapset tässä yhteydessä määrittyy. Etsin vastausta näihin kysymyksiin analysoimalla Videox-videoiden ja Kids Top20 -ohjelman audiovisuaalisia representaatioita ennen kaikkea toimijuuden käsitteen avulla sekä painottaen musiikin esittämiseen ja tanssimiseen liittyviä ääniä ja kuvia. Populaarimusiikkiin liittyvistä vahvoista etnisyyskäsityksistä sekä tanssin ruumiillisuudesta johtuen analyysini kohdistuu erityisesti etnisyyden ja sukupuolen esitystapoihin.

Toimijuuden käsite kumpuaa viimeaikaisesta yhteiskuntateoriasta, jossa sillä on keskeinen sija yhteiskunnallisten rakenteiden vastaparina. Tämän jossain määrin dualistisen mallin mukaan sosiaalinen todellisuus rakentuu yhtäältä ihmisyksilöiden tekojen ja tietoisuuden sekä toisaalta yhteisöllisten sääntöjen ja reunaehtojen varaan. Yksilöllisyys ja yhteisöllisyys vaikuttavat kuitenkin toinen toisiinsa kehämäisesti, sillä nojatessaan yhteisöllisiin sääntöihin yksilöllinen toiminta tuottaa yhteiskunnallisia rakenteita ja instituutioita, jotka edelleen säätelevät yhteisöllisiä sääntöjä. (King 2009: 262-263.) Näin ollen toimijuuden analyysi tarkoittaa huomion kiinnittämistä siihen, miten erilaiset identiteettipoliittiset kategoriat kytkeytyvät erilaisiin institutionalisoidun vallankäytön muotoihin: mitä esimerkiksi lapset voivat ja saavat tehdä valtakunnallisen televisiomedian kontekstissa?

\section{Visuaalisesta audiovisuaaliseen kulttuuriin}

Viime aikoina kulttuurista merkityksenantoa koskevissa analyyseissa on korostettu voimakkaasti niin sanottua visuaalista kulttuuria eli sitä, miten varsinkin nykyisissä jälkiteollisissa yhteiskunnissa kuvallinen viestintä on lisääntynyt ja muodostaa yhä keskeisemmän osa-alueen merkitysten muodostamisessa. Ilmiön voi havaita esimerkiksi viimeaikaisessa suomenkielisessä tutkimus- ja tietokirjallisuudessa: Janne 
Seppäsen (2005) kirjoittaman Visuaalinen kulttuuri -kirjan rinnalle on ilmestynyt Leena-Maija Rossin ja Anita Sepän (2007) toimittama Tarkemmin katsoen -artikkelikokoelma, joka alaotsikkonsa mukaan on "visuaalisen kulttuurin lukukirja". Lisäksi Juha Herkmanin (2007) tuoreessa kriittisen mediakasvatuksen yleisesityksessä visuaaliselle kulttuurille omistetaan kokonainen luku. Seppänen (2005: 17) kirjoittaakin nimenomaan 1900-luvusta visuaalisen kulttuurin ja sen alustana toimineen mediajulkisuuden kasvun aikakautena. Samaan tapaan myös Herkman (2007: 63) pitää oikeutettuna väittää, "että kuvakulttuurin merkitys on monessa suhteessa tullut aiempaa näkyvämmäksi ja vaikutusvaltaisemmaksi ihmisten arjessa".

Ei voi kiistää, etteikö kuvallisten viestien tulkintaoppaille olisi oma tarpeensa. Elokuvat, televisio, Internet sekä lehtien sivuilla ja katujen varsilla olevat mainokset ovat täynnänsä kuvia, jotka viestivät esimerkiksi autuaallisista autoista, ihanteellisista ihmiskehoista tai esimerkillisistä elämäntavoista - oli näillä lääke- tai muu tieteellinen perustansa tai ei. Silti on omalaatuista, että kuvakulttuurin tutkimuksissa audiovisuaalinen viestintä pelkistyy yleensä vain kuvallisten sisältöjen erittelyyn ja analyysiin. Toisin sanoen audiovisuaalisesta vaikuttaa tulevan tiettyjen mediateknologioiden (elokuva, televisio, Internet) määre sen sijaan, että merkityksenantoa pohtivissa analyyseissa kiinnitettäisiin huomiota kuvallisten ja äänellisten ilmiöiden yhteenkuuluvuuteen.

Visuaalisen kulttuurin tutkijoiden kunniaksi on kuitenkin todettava, että pätevinä kriittisinä ajattelijoina he huomauttavat tarpeesta suhteellistaa visuaalista aikakautta koskevaa puhetta. Esimerkiksi Seppänen (2005: 22) korostaa sitä, että monet visuaalisen kulttuurin piiriin lukeutuvat esitysmuodot perustuvat audiovisuaalisille teknologioille, minkä johdosta "elämme paitsi kuvan myös äänen aikakautta". Herkman (2007: 63) puolestaan vie ajatusta edemmäs esittämällä, että "[n]ykykulttuuria leimaa pikemminkin kaikenlaisten informaatio- ja viihdemuotojen samanaikainen kakofonia kuin jonkin tietyn ilmaisumuodon ylivalta." Nämä ajatukset voi edelleen yhdistää esimerkiksi Mikko Lehtosen (2002) korostamaan teoriaan multimodaalisuudesta. Lehtosen (2002: 47-48) mukaan on mahdollista puhua sekä tekstuaalisesta että kulttuurisesta multimodaalisuudesta: edellinen liittyy siihen, että "kieli ja muut symbolit eivät koskaan esittäydy ikään kuin sellaisinaan, vaan kohtaamme ne aina jossakin materiaalisessa muodossa, joka tuo oman lisänsä merkitysten muodostumiseen", kun taas jälkimmäisen lähtökohtana on se, että eri mediamuotoja "ei tulisi tarkastella ikään kuin ne olisivat olemassa muista mediamuodoista riippumatta, vaan lähtökohtana tulisi olla kunkin muodon kytkeytyminen muihin mediamuotoihin". 
Lehtosta mukaillen voi korostaa vielä sitä, että mikäli modaalisuuden ytimessä on kysymys eri modaliteeteista, keskustelu koskee ennen kaikkea eri symbolien luotettavuutta. "Yleisesti ottaen pidämme näköaistia luotettavampana kuin kuuloa", hän summaa (Lehtonen 2002: 53).

Sikäli onkin kiinnostavaa, että vaikka niin Lehtonen (2002: 51) kuin Seppänenkin (2005: 24) korostavat "silmäkeskisyyttä" kartesiolaisine keskeisperspektivismeineen keskeisenä moderniteettia määrittävänä ideologisena ajatusrakennelmana, perustuu heidän tarkastelunsa pikemminkin tämän ajatusrakennelman dekonstruktioon kuin esimerkiksi multimodaalisten vaihtoehtojen etsimiseen. Toisin sanoen he omilla metodisilla valinnoillaan ikään kuin hyväksyvät visuaalisen kulttuurin ylivallan. Niinpä esimerkiksi siitä huolimatta, että Lehtonen (2002: 49) painottaa pyrkimystä "kehittää aidosti multimodaalista merkitysteoriaa, jossa lähtökohtana on eri muotojen esiintyminen ja vaikutus rinnan", päätyy hän käsittelemään lähinnä vain kirjoitetun kielen ja kuvan suhdetta. "Näköpiirissä olevassa tulevaisuudessa on käynnissä siirtymä luku- ja kirjoitustaidon hallitsevuudesta visuaalisuuden merkityksen kasvuun", hän kirjoittaa (Lehtonen 2002: 58). Aivan kuin multimodaalisuutta koskevasta teoretisoinnista olisikin yhtäkkiä jollakin kumman tavalla tullut peruste yhden modaliteetin eli kuvan tarkastelulle ja ensisijaisuudelle.

Sitä, että auditiivisen kulttuurin lukukirjoja ei liiemmälti ole (vielä) julkaistu, voikin pitää osoituksena tietynlaisen "uskon vasta kun näen" -epistemologian hallitsevasta asemasta (ks. Bull \& Back 2003: 1-3). Kuten Lehtonenkin (2002: 51; kursivointi lisätty) huomauttaa, "[n]äköaistin priorisointi näkyy myös tieteen kielessä" - esimerkkeinä hän käyttää muun muassa sellaisia "sinänsä viattoman kuuloisia sanoja" kuten näkemys, näkökulma, katsaus, yleiskuva, kaukonäköinen ja synopsis. Äänilähtöisen yhteiskunnallisen ja kulttuurisen analyysin puolesta puhuvat sosiologit Michael Bull ja Les Back (2003: 2-3) kuitenkin aiheellisesti korostavat, että kysymys ei ole visuaalisen syrjäyttämisestä, vaan "aistien demokratiasta". Toisin sanoen kysymys on siitä, että äänellä (ja muillakin aisteilla) on yhtälailla olennainen osuus maailman kokemisessa ja ymmärtämisessä kuin näöllä. Mikäli tätä ei tunnusteta, riskinä on "näköaistiin perustuva epistemologia", joka on "sekä riittämätön että usein virheellinen sosiaalista maailmaa koskevissa luonnehdinnoissaan, analyysissa ja täten myös ymmärryksessään" (Bull \& Back 2003: 3).

Bullin ja Backin (2003: 3-4) metodinen ehdotus yksipuolisesti kuvallisten esitystapojen tarkastelun täydentämiseksi on erityinen "syväkuuntelu", jossa huomiota kiinnitetään tietyn äänellisen ilmiön moninaisiin potentiaalisiin merkityskerrostu- 
miin. Tällöin keskeistä on pohtia sitä, miten äänen avulla voi arvioida uudelleen sosiaalisten, ihmisiin ja paikkohin liittyvien kokemusten sekä yhteisö- ja valtasuhteiden merkitystä, luonnetta ja painoarvoa. Musiikkia ajatellen Bull ja Back (2003: 6-11) mainitsevat siihen liittyvän yhteisöllisyyden, eksoottisen "viettelevyyden", kysymyksen melun ja musiikin rajasta sekä ruumiillisen liikkeen kontrolloinnin muun muassa tanssin avulla. Toisin sanoen musiikki (tai melu) on aina yhteisöllinen tapahtuma, jossa erilaiset identiteetit ja käytännöt kohtaavat. Kielen ja asujen lisäksi erilaiset sävelkulut, soitinten äänet ja kokonaiset genret viestivät erilaisista yhteisöllisyyden muodoista: "yleisö kuuli 'me' vaikka laulaja sanoi 'minä'", kuten John Coltranen suuhun pantu lentävä lause kuuluu (ks. McClary 2003: 431; Bull \& Back 2003: 6). Musiikkivideoita Bull ja Back (2003: 14) pitävät erityisen keskeisinä juuri musiikkigenrejen rodullistamisessa: heidän mukaansa R\&B ja hip-hop on sysätty "ghettojen mustuuteen", kun taas rock ja kantri edustavat "vaniljalähiöitä ja maaseudun valkoisia sisätiloja".

Omaa aineistoani eli Videox-sarjaa ja Kids Top20 -ohjelmaa ajatellen syväkuunteluun nojaava audiovisuaalisten mediarepresentaatioiden analyysi pohjautuu kolmeen yksityiskohtaisempaan ongelmakenttään:

1) Millaisia esiintyjiä lapset ovat? Miten he esiintyvät videoilla ja muussa ohjelmasisällössä? Soittavatko he (mitä), tanssivatko, "fanittavatko"?

2) Millaisia sosiaalisia identiteettejä lasten musiikkivideoiden musiikkiesityksillä rakennetaan yleensäkin ja miten? Millaisia aikuisroolimalleja videoissa esitetään?

3) Mihin lajityyppeihin eli genreihin lasten musiikkivideot kytkeytyvät ja millaisiin sosiaalisiin identiteetteihin ne tätä kautta liittyvät? Mitä on lastenmusiikki tämän perusteella?

\section{Hiljaiset lapset XXL-asuissaan}

Syväkuunnellessa Kids Top20:ssa esitettäviä ja Videox-musiikkivideoita huomio kiinnittyy väistämättä siihen, että videoissa lasten itsensä tuottamat äänet ovat jokseenkin olemattomia. Onkin erikoislaatuista, että vaikka YLEn verkkosivuilla Videox-videoiden kerrotaan olevan koululuokkien suunnittelemia ja toteuttamia, tämä koskee vain kuvallista puolta: oppilaat "saavat käteensä kameran ja biisin". Toisin sanoen musiikillinen toteutus on valmiina etukäteen, ja sen sovituksesta kunnia annetaan Petri Koskimäelle. Videox-kappaleiden laulajina puolestaan ovat Hanna 
Salo ja Mikko Pohjola. (YLE 2005.) Kids Top20 -ohjelmassa esitettävien videoiden musiikki taas on yleensä nykyhetken populaarimusiikin yleisten suosikkiartistien esittämää: esimerkiksi vuoden 2009 euroviisuviikolla 20 ohjelman listanimet olivat Lady GaGa, Laura Vanamo, Waldo's People, Pete Parkkonen, Hannah Montana, RA, Alesha Dixon, Cheek, Corbin Bleu, Jonas Brothers, AC/DC, Akon, Apulanta, Enrique Iglesias feat. Ciara, Flo Rida feat. Kesha, Koop Arponen, Sturm und Drang, Haloo Helsinki, Monday ja Mando Diao (KT20 2009).

Kuvallisen ilmaisun osalta Kids Top20 ja Videox-videot ovat kuitenkin ratkaisevasti erilaisia. Kids Top20:n videot ovat valtavirran ammattilaistuotteita, kun taas Videox-sarjan lähtökohtana on ollut se, että lapset itse "lavastavat, puvustavat, maskeeraavat, näyttelevät ja kuvaavat" (YLE 2005). Niinpä Videox-videoissa ei aikuisesiintyjiä näy Saku Sammakossa vilahtavaa autokuskia ja videokuvaajaa lukuun ottamatta, ja laulujen sanoissa mainitut tai muuten keskeiset aikuismaailman hahmot - Intiaanin sotahuudon apassit ja kullankaivajat, Jörö-Jukka-rockin opettaja, Känkkäränkän vanhemmat, Meksikon pikajunan konduktöörit, rosvot ja matkustajat, Rosvolaulun poliisit - ovatkin kaikki lasten esittämiä. Jörö-Jukka-rockissa ja Rosvolaulussa lapset tunkeutuvatkin aikuismaailmaan korostetusti asustuksellaan: niin opettajan kuin poliisienkin asut ovat selvästi muutaman kokonumeron verran turhan kookkaita (kuvat 1 ja 2).

Epäsuhtaisiin asusteisiin pukeutuminen on käytetty komiikan keino, mutta lasten yllä erilaiset virkamiesasut herättävät omia yhteiskuntakriittisiä kysymyksiään: kuinka pitkälle esimerkiksi opettajan asu on tulkittavissa avoimine paidankauluksineen ja löysine solmioineen huolittelemattomaksi sekä pikkutakki-solmio-yhdistelmänä vanhakantaiseksi, ja täten edelleen lasten ehdoilla esitetyksi kritiikiksi yhtä keskeistä yhteiskunnallista auktoriteettiasemaa kohtaan? Pikkutakkejahan valmistetaan massatuotantona myös alle kouluikäisille lapsille. Poliisitakin asema viranomaisunivormun osana puolestaan on erilainen, sillä sen käytöstä on omat asetuksensa Suomen laissa ja esimerkiksi käyttöön teatteriesityksissä on saatava poliisipäällikön lupa (Poliisi 2009). Näin ollen lasten ylle puettuna virallinen poliisipuku on väistämättä liian suuri ja siten mahdollisesti koominenkin, mutta tällöin tämäkin pikemminkin vahvistaa kuin kritisoi kyseisen viranomaisen toimintaa, varsinkin kun laulussa ja videolla poliisit onnistuvat saamaan rosvot kiinni: oikea poliisi on aikuinen ja sellaisena hänen edellytyksensä napata rikolliset ovat vain paremmat. Toisin sanoen lasten mahdollisuudet erilaisten aikuisauktoriteettiasemien kyseenalaistamiseen ovat erilaiset jo vaateparren valinnan perusteella. 

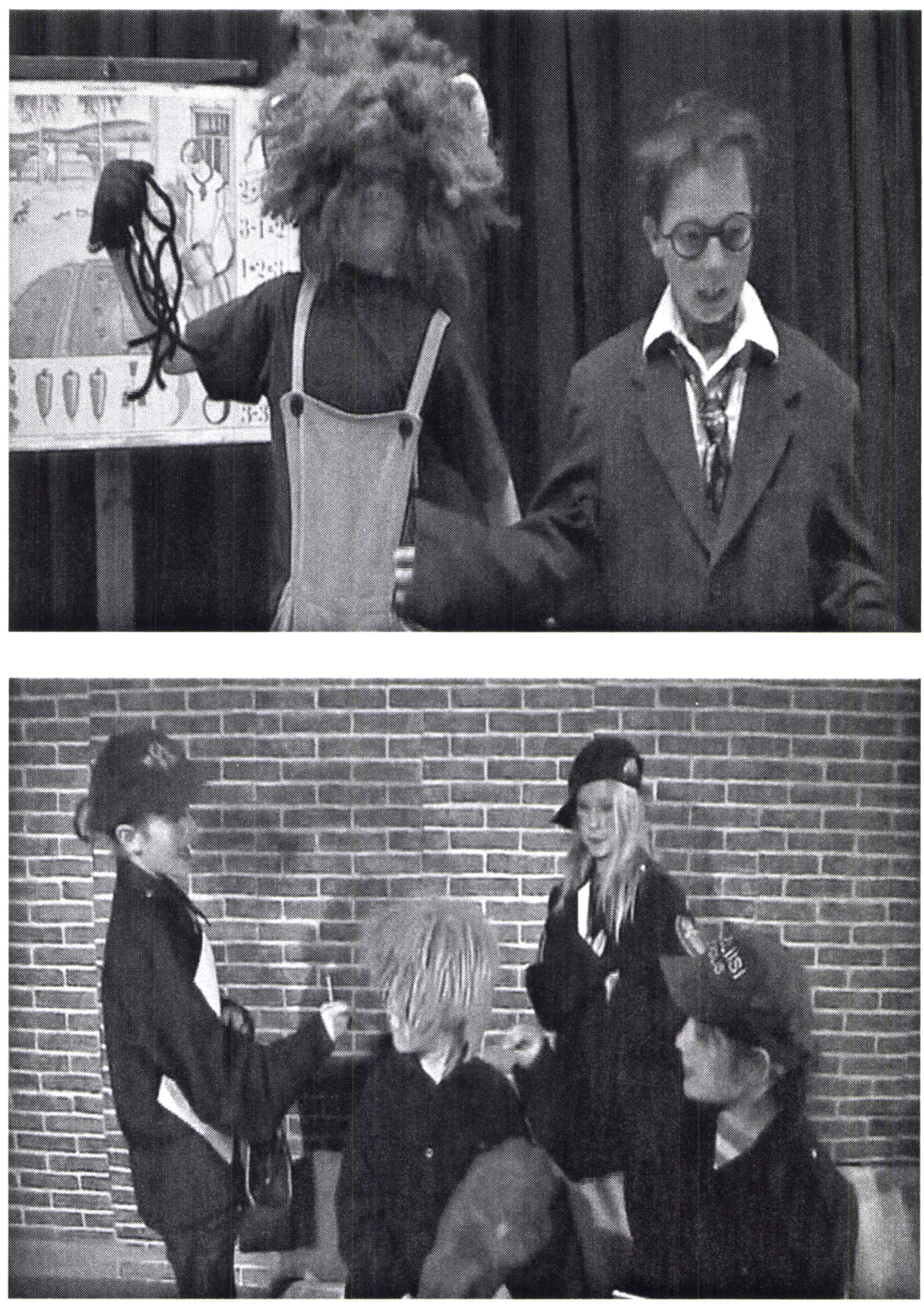

Kuvat 1 ja 2. Opettaja ja poliisi pitkine hihoineen Videox-videoissa JöröJukka-rock ja Rosvolaulu. 


\section{Tytöt, teknofallos ja muut soittimet}

Musiikkivideoita on luokiteltu visuaalisten sisältöjensä ja esitystapojensa perusteella useilla eri tavoilla (ks. esim. Kaplan 1987; Goodwin 1992), mutta yksi suoraviivaisimmista jaotteluista on jo 1980-luvulle palautuva musiikkiteollisuuden parissa käytetty erottelu esittäviin, kertoviin ja käsitteellisiin videoihin (Frith 1988). Lisäksi olen suomalaisten musiikkivideo-ohjaajien kanssa käymissäni keskusteluissa pannut merkille, että heillä on tapana jakaa videot vielä tiiviimmin pelkästään "soitto-" ja "tarinavideoihin". Olennaisinta tässä yhteydessä kuitenkin on, että kuvat musiikin soittamisesta ovat tuiki tavallisia elleivät peräti puolipakollisia musiikkivideoiden visuaalisia elementtejä. Niinpä myös Videox-videoissa on useita soittokohtauksia, joskin näiden osuus ajallisesti mitattuna on selvästi vähäisempi kuin laulujen sanojen mukaisen tarinankerronnan. Joka tapauksessa Saku Sammakossa Hillevi Hiiren ja Hepokatti-Heikin häitä säestää puolen tusinan soittajan orkesteri johtajineen, ja toisessa kohtauksessa Hepokatti-Heikki itse istuu portailla viulua soittaen. Kuningaskobrassa on siinäkin isohko, seitsemän hengen ryhmä soittajia. Pöllörockissa esiintyvään bändiin kuuluu viisi soittajaa, kun taas Mörri-Möykyn bändikohtauksessa on peräti yhdeksän esiintyjää ja seuraavassa kuorokohtauksessa kolmessa rivissä kaiken kaikkiaan kuusitoista. Jörö-Jukka-rockissa puolestaan ainoa kuvissa näkyvä instrumentalisti on itse Jörö-Jukka, joka esiintyy alun ja lopun tanssikohtauksissa (leikki)sähkökitara käsissään. Lisäksi joukko "pikkuoravia" soittaa pariin otteeseen ilmakitaraa, osalla tyyny sylissään (kuva 3).

Soittimet ovat erityislaatuisia esineitä. Etnomusikologi Veronica Doubleday (2008: 3-4) huomauttaa, että koska musiikillista ääntä ajatellaan usein jollakin tapaa transformatiivisena eli toisenlaiseen tietoisuuteen viittaavana tai jopa siirtävänä, soittimen omistus tai soitto liittyy kysymyksiin sosiaalisista valtasuhteista. Näin ollen soittimet myös henkilöityvät eri tavoin: niistä voi tulla taikaolentojen kaltaisia, eikä kuka tahansa voi välttämättä soittaa niitä tai väittää niitä omakseen. Nämä ajattelu- ja toimintamallit puolestaan liittyvät tiiviisti kysymyksiin sukupuolisuudesta, ja Doubleday (2008: 5) väittääkin juuri miespuolisten ammattimuusikoiden kunnostautuneen yleisesti poissulkevien soitinkäytäntöjen ylläpidossa. Esimerkiksi sähkökitarasta on populaarimusiikintutkija Steve Waksmanin (1999: 5-6, 244) mukaan rockkulttuurissa muodostunut niin jykevä "teknofallos", että yleisön on jopa helpompi uskoa kitaristin olevan naisen näköinen mies kuin fysiologisesti ajatellen tosiasiallinen nainen. 


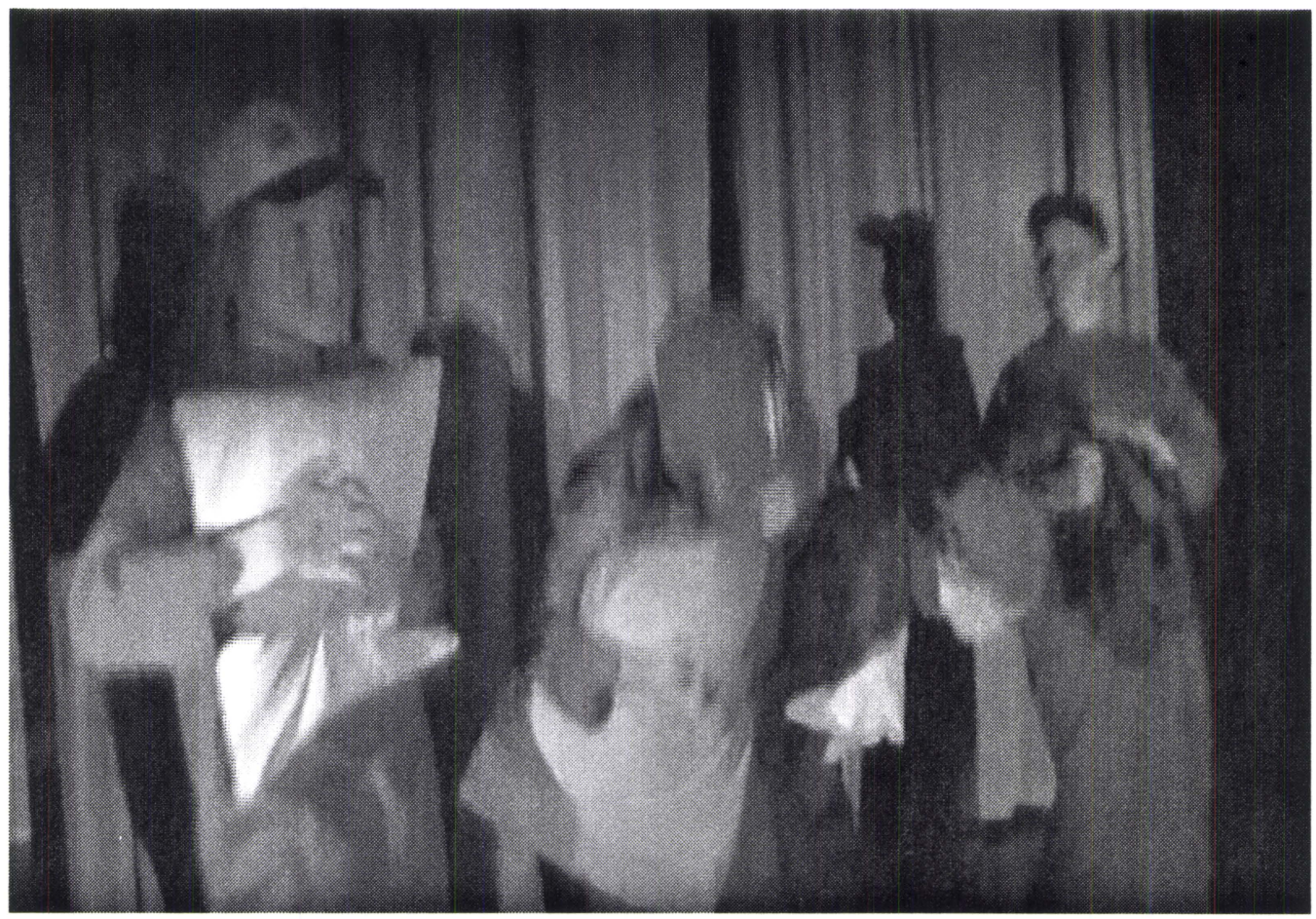

Kuva 3. Ilmakitaraa tyynyillä soittavat "pikkuoravat" moshaavat Jörö-Jukkarockissa.

Sähkökitaran yltiömaskuliinisuutta ei haasteta Videox-videoissakaan. Jörö-Jukan lisäksi sointinta käsittelee käkikellomaskiin naamioitunut lapsi Pöllörockissa (kuva 4). Naamarin takia soittajan sukupuolesta on hankala saada yksiselitteisesti selvää, mutta muu asustus sekä naamarin takaa näkyvä tukka viittaavat poikaan. Olennaisempaa kuitenkin on, että vaikka soittaja olisikin tyttö, tätä sähkökitaran "pyhäinhäväistystä" ei tehdä selvästi näkyväksi. Lisäksi vaikka rockbändeissä basistin paikka on huomattavasti useammin avoinna myös naisille kuin kitaristin, ainoat Videox-sähköbasistit Kuningaskobrassa ja Pöllörockissa ovat molemmat poikia (joskin Pöllörockissa basistin sukupuolen määritys onnistuu samoin varauksin kuin kitaristinkin). Saku Sammakossa sen sijaan sekä kitara että basso ovat akustisia, mutta soittajat osoittautuvat tarkkaan katsottuina silti pojiksi - kuten hääorkesteria johtava kapellimestarikin (kuva 5). 


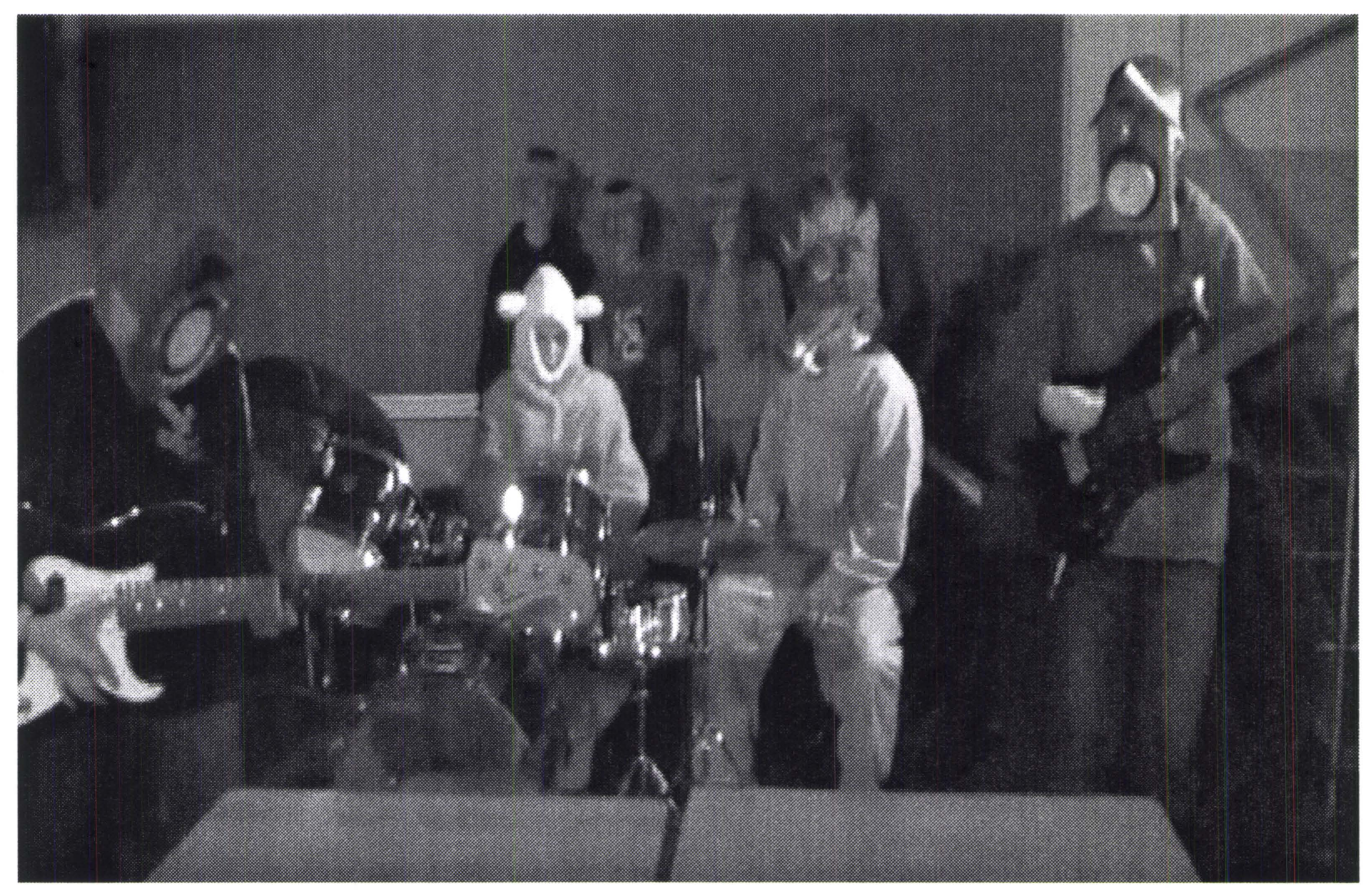

Kuva 4. Pöllörock-bändin basisti, pari rumpalia ja sähkökitaristi.

Populaarimusiikin sukupuolittuneita esiintymiskonventioita vastaa myös se, että Mörri-Möykyn loppupuolella olevassa peräti yhdeksän hengen bändikohtauksessa laulusolistit ovat molemmat tyttöjä (kuva 6). Populaarimusiikintutkija Sheila Whiteley (2000: 3-5) on huomauttanut siitä, miten populaarimusiikki on yleisesti ottaen kaikilta osa-alueiltaan erittäin miesvaltainen kulttuurinen käytäntö. Esityskokoonpanoja ajatellen tyypillisintä on, että naiset ovat laulajia - soitinten ja varsinkin sähkökitaran virtuoosimainen käsittely on täten miehisen ylivertaisuuden osoitus (Bayton 1997: 37; ks. myös Carson ym. 2004: 3). Tämä pitää paikkansa myös Videoxvideoiden perusteella, sillä 17 musisoivasta tyttöesiintyjästä 11 laulaa, kun taas 28 poikaesiintyjästä laulajia on vain 7 ja hekin kaikki Mörri-Möykyn kuorossa (ks. taulukko 1). Lisäksi jäljelle jäävät kuusi tyttösoittajaa soittavat kaikki lyömäsoittimia, joista niistäkin kaksi kolmasosaa ovat marakassin kaltaisia "helppoja" koulusoittimia. Poikien soitinvalikoima on selvästi laajempi ja soittimet ovat isompia sekä rakenteeltaan ja soittotavoiltaan monimutkaisempia: muun muassa piano, congat, pystybasso ja kokonainen rumpupatteristo. 


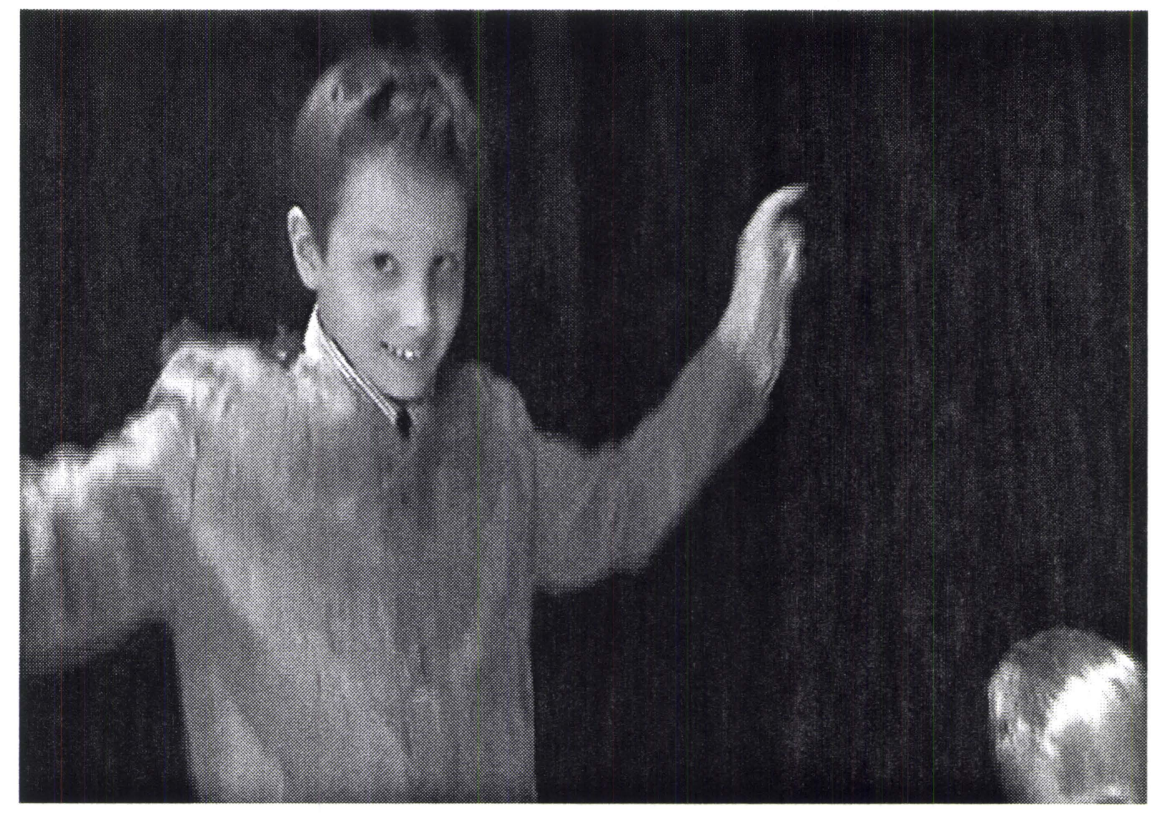

Kuva 5. Hääorkesterin kapellimestari Saku Sammakossa.

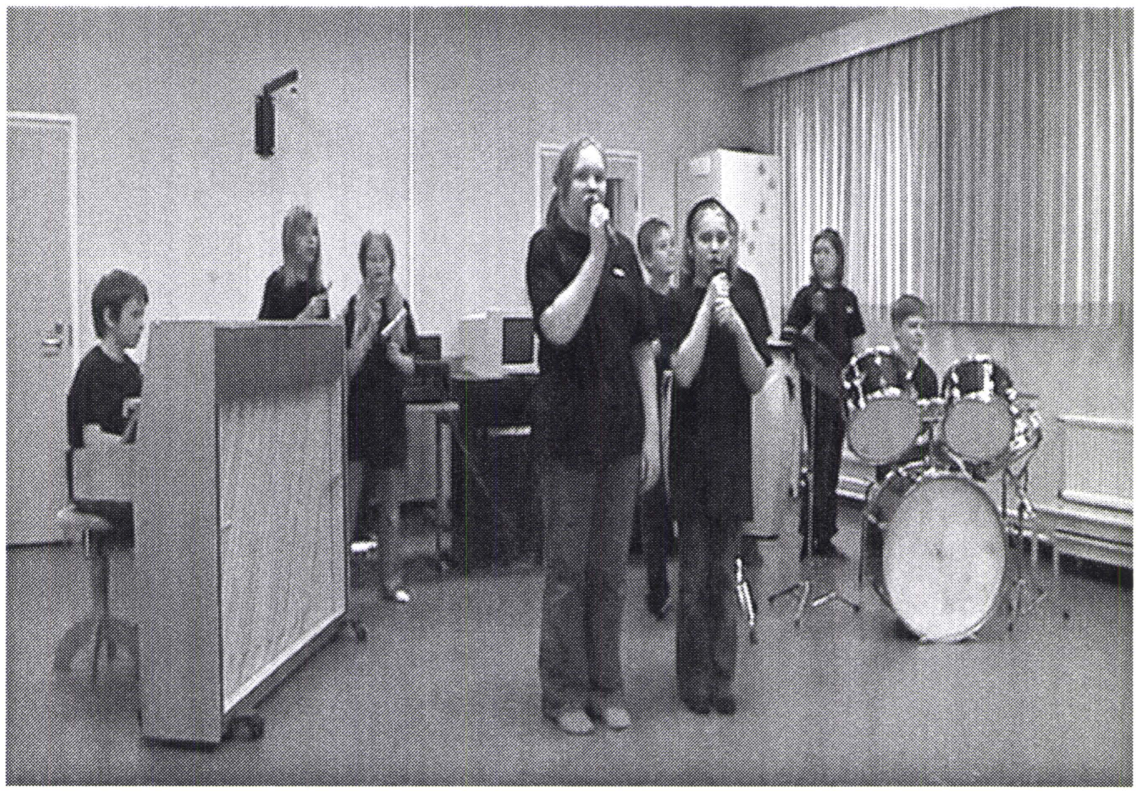

Kuva 6. Mörri-Möykyn bändi. 


\begin{tabular}{|c|c|c|}
\hline Video & pojat & tytöt \\
\hline Saku Sammakko & $\begin{array}{l}\text { kapellimestari } \\
\text { virvelirumpu } \\
\text { bongot } \\
\text { trumpetti } \\
\text { pystybasso } \\
\text { akustinen kitara } \\
\text { viulu }\end{array}$ & - \\
\hline Kuningaskobra & $\begin{array}{l}\text { iso djembe } \\
\text { bongot } \\
\text { virvelirumpu } \\
\text { sähköbasso }\end{array}$ & $\begin{array}{l}\text { "shaker" (putkihelistin) } \\
\text { pieni djembe } \\
\text { pieni djembe }\end{array}$ \\
\hline Pöllörock & $\begin{array}{l}\text { sähköbasso } \\
\text { rummut } \\
\text { virvelirumpu } \\
\text { sähkökitara } \\
\text { kosketinsoitin }\end{array}$ & - \\
\hline Känkkäränkkä & - & - \\
\hline Rosvolaulu & - & - \\
\hline Meksikon pikajuna & - & - \\
\hline Mörri-Möykky & $\begin{array}{l}\text { piano } \\
\text { rummut } \\
\text { congat } \\
\text { marakassi } \\
\text { kuoro (7) }\end{array}$ & $\begin{array}{l}\text { penaali-rytmisoitin } \\
\text { penaali-rytmisoitin } \\
\text { laulu } \\
\text { laulu } \\
\text { marakassi } \\
\text { kuoro (9) }\end{array}$ \\
\hline Jörö-Jukka-rock & (leikki)sähkökitara & - \\
\hline Intiaanin sotahuuto & - & - \\
\hline yhteensä & 28 (ilman kuoroa 21) & 17 (ilman kuoroa 8) \\
\hline
\end{tabular}

Taulukko 1. Videox-videoiden soittajat sukupuolittain ryhmiteltynä. 
Jörö-Jukan sähkökitarointi on identiteettipoliittisessa mielessä kiinnostava vielä siitäkin syystä, että hänen pörrötukkainen hahmonsa (ks. kuva 1 edellä) sekä siihen liittyvät mielleyhtymät ja Jörö-Jukka-rockin sanat yleisestä epäsiisteydestä on vaivaton yhdistää rockin katu-uskottavuutta korostavaan ajatteluun. Toisin sanoen rockin ajatellaan usein olevan tavalla tai toisella rähjäistä, elämän kuluttamaa ja vastarintaista tai jopa kapinallista: päihdeongelmat, satunnaiset seksisuhteet ja karkea kielenkäyttö ovat rockpiireissä tämän käsityksen mukaan pikemminkin sääntö kuin poikkeus. Jörö-Jukka-rockin sanoissa pikkuoravat Nestori, Simeoni ja Elmeri ovat ne, jotka kapinoivat opettajan auktoriteettiasemaa vastaan, mutta rockin, sähkökitaran ja kapinallisuuden liitto saa vahvan visuaalisen ilmaisunsa myös videon lopussa: Jörö-Jukka lyö sähkökitarallaan opettajan tainnoksiin (kuva 7).

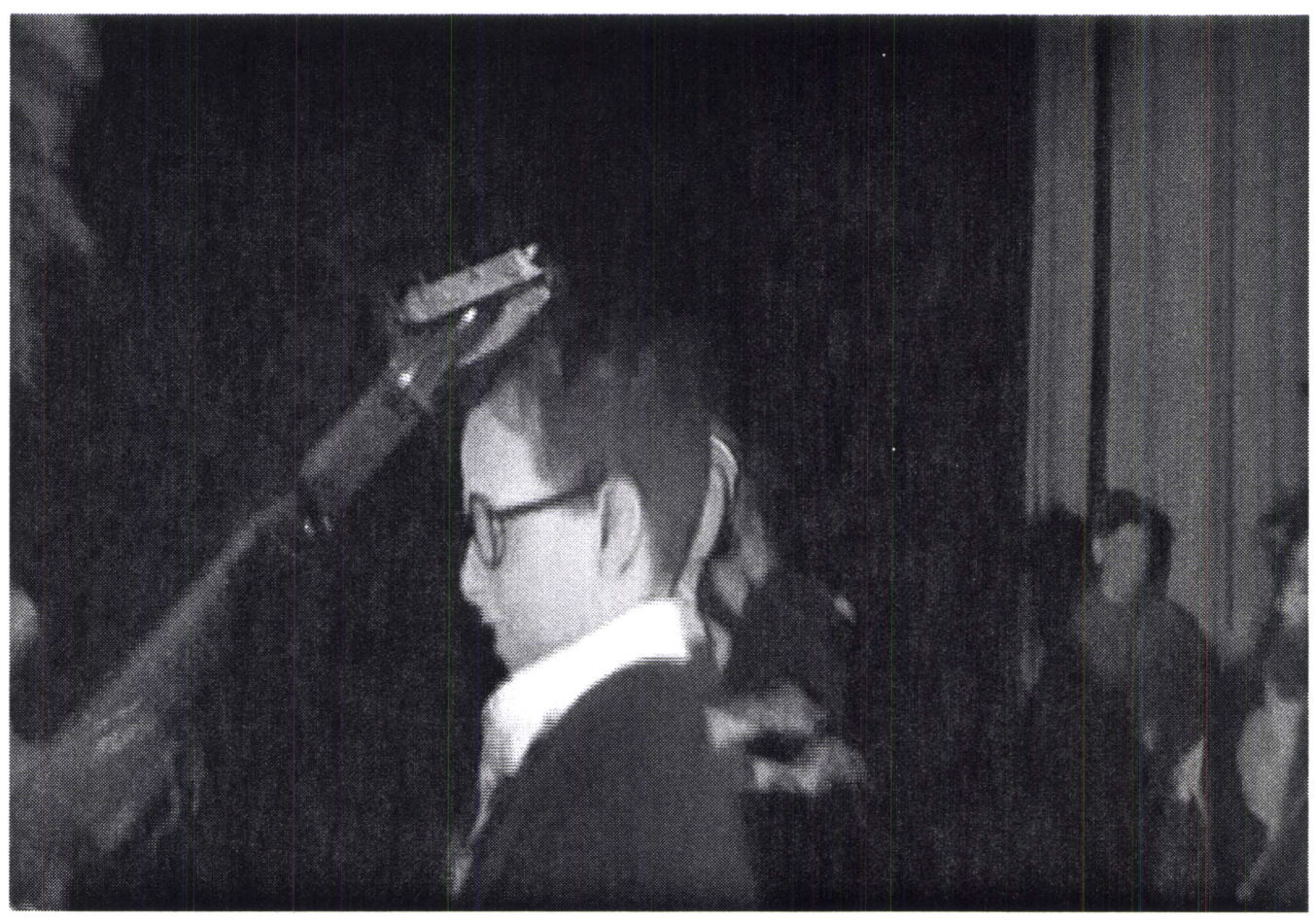

Kuva 7. Jörö-Jukka lyö kitarallaan opettajaa päähän. 


\section{Letkajenkalla homofobiaa vastaan}

Soiton ohella myös tanssi on keskeinen musiikkivideoiden osatekijä, joskin sen toteutuksessa ja määrittelyssäkin musiikinlajilla on usein suuri painoarvo (ks. Kärjä 2008). Musiikkivideoiden ja tanssin yhteyttä on kuitenkin tutkittu sangen vähän, vaikka väline ja koreografiat tarjoavat monipuolisia lähtökohtia niin taloudellisten, ruumiillisiin ihanteisiin liittyvien kuin identiteettipoliittistenkin kysymysten käsittelyyn (Buckland 1998: 278-280; Vernallis 2004: 71, 285). Varsinkin sukupuolisuuden suhde tanssiin on herättänyt runsaasti keskustelua, ja esimerkiksi tanssintutkija Ramsay Burtin (1995: 50-53) mukaan niin sanotuissa länsimaisissa yhteiskunnissa "ongelman" ytimessä on tanssivan miesruumiin ja yleisön oletetun "miehisen katseen" välinen jännite. Myös konventionaaliset patriarkaaliset käsitykset yhdenmukaisesta maskuliinisuudesta joutuvat koetukselle miehen tanssiessa, ja niinpä ei olekaan yllättävää, että nimenomaan baletissa ja muussa länsimaisessa taidetanssissa aktiiviset pääroolit on varattu miehille, kun taas naiset ovat usein katseen ja toiminnan kohteita. Miesten tanssiin liittyy lisäksi pinttyneitä heteronormatiivisia ja suorastaan homofobisia ajattelumalleja: miestutkija Jukka Lehtonen (1999: 137-139) huomauttaakin siitä, miten tällaisia käsityksiä ylläpidetään esimerkiksi koulujen vanhojentansseissa: "Jos tytöt eivät löydä itselleen paria pojista, he voivat tanssia keskenään. Sen sijaan pelkkiä poikapareja tuskin esiintyy."

Sekä Videox-videoissa että Kids Top20:ssa tanssitaan usein, mutta varsinaiset paritanssikohtaukset ovat harvinaisia: Videox-videoissa tällainen on ainoastaan Saku Sammakossa, jossa Hillevi Hiiri ja Hepokatti-Heikki juhlistavat liittoaan häätanssilla (joka ei askelluksen perusteella kuitenkaan liene valssia). Kids Top20:ssa taas koululaisstudioyleisö tanssii kyllä ahkerasti ohjelmassa esitettävien musiikkivideoiden soidessa, mutta pääsääntöisesti ilman paritanssiotteita. Osuvan esimerkin populaarimusiikin, tanssin ja sukupuolisuuden suhteesta tarjoaa 26.11.2006 esitetty jakso, jossa vieraina olivat Maija Vilkkumaa sekä Lovex-yhtyeen laulaja Theon (oik. Torsti Mäkinen) ja basisti Jason (oik. Timo Karlsson). Vieraiden haastattelujen jälkeen heidät nähdään tanssimassa lapsijoukon ja ohjelman juontajan Tean (Hiilloste) kanssa, joskin Lovexista vain Theon tanssii. Basistivitseistä huolimatta Jasonin katoaminen ohjelmasta tanssin alkaessa on omiaan vahvistamaan oletusta "vauhdikkaan rockin" (Lovex 2009) tai alternative/glam/hard rockin (Wikipedia 2009) ja tanssin yhteensopimattomuudesta: rokkarit ovat kovia kundeja, eivätkä kovat kundit tanssi. Rockmusiikin historiikeissa tanssista kirjoitetaankin etupäässä vain twistin 
kaltaisten "tanssihullutusten" yhteydessä (ks. Garofalo 1997; Covach 2007), ja albumikeskeisen rockin kulta-ajalla 1970-luvulla monet rokkarit pyrkivät erottautumaan erityisesti discomusiikista kaikin keinoin (Straw 2001: 170). Toisaalta Theonin - samoin kuin niin ikään rock-kategoriaan yhdistetyn Maija Vilkkumaan - tanssi asettaa tällaisen oletuksen kyseenalaiseksi, ja olennaisempaa vaikuttaakin olevan se, millainen rokkariruumis tanssii. Toisin sanoen kysymys koskee tanssin yhteyttä sukupuolisuuden rakentumiseen rock-kontekstissa: onko siis niin, että Theon vaaleana pitkähiuksisena, kapeampikasvoisena ja muutenkin kevytrakenteisempana (kuva 8) on selvästi androgyynimpi kuin Jason ja siten ikään kuin hyväksyttävämpi rokkaritanssija? Theon on lisäksi selvästi androgyynimpi kuin Vilkkumaa (kuva 9), joka naisena puolestaan vastaa tanssin feminiinisyyttä korostavia ajattelumalleja.

Vilkkumaan ja Theonin tavat tanssia lasten joukossa eroavat silti ratkaisevasti toisistaan juuri paritanssiotteiden suhteen. Lovex-videon aikaisen tanssikohtauksen alussa Theon tanssii ilman fyysistä kontaktia muihin tanssijoihin, liikuttaen kaulaansa korostetusti edestakaisin ja pitäen käsiään "egyptiläisessä" asennossa (kuva 10). Ottaen huomioon sen, että ohjelmassa soitettava kappale Bullet for the Pain ei tyylilajiltaan tai yksittäisempien musiikillisten keinovarojensa osalta viittaa varsinaisesti musiikilliseen orientalismiin esimerkiksi asteikkojen, sävelkulkujen tai laulutavan perusteella (ks. esim. Scott 2003: 155-178), Theonin tanssitavan voi tulkita humoristiseksi tai muuten vähemmän vakavaksi. Tällainen tulkinta puolestaan vahvistaa ajatusta, että tosi rokkarit eivät tanssi - tai ainakaan he eivät tanssi tosissaan.

Tanssikohtauksen seuraavassa otoksessa Theon puolestaan tanssii yleisöön kuuluvan vaaleapaitaisen tytön kanssa ensin suljetussa otteessa ja sitten pyöräyttäen tätä käsivartensa alta (kuva 11). Tanssiin liittyvää heteronormatiivisuutta ja homofobisuutta ajatellen keskeisiä kysymyksiä ovat ensinnäkin se, miksi Theon tanssii juuri tytön kanssa, ja toiseksi se, miksi Vilkkumaa ei oman videonsa aikana tanssiessaan kosketa ketään, ei tyttöjä eikä poikia. Yleisesti ottaen yleisön jäsenet eli lapset vaikuttavat olevan tanssissa mukana tasapuolisesti sukupuolesta riippumatta, joskin juuri Theonin paritanssi ja Vilkkumaan yksintanssi vihjaavat siihen suuntaan, että mies ja esiteini-ikäinen tyttö on suotavampi tanssipari kuin nainen ja esiteini-ikäinen poika. Näin viidesluokkalaisten tyttöjen toimijuus suhteessa rockkulttuuriin osoittautuu patriarkaalisten toimintamallien säätelemäksi: yhteiskunnan täysivaltaisella miespuolisella jäsenellä on oikeus ikään kuin merkitä kumppaninsa tai ainakin vahvistaa oletusta tämän heteroseksuaalisesta identiteetistä melkeinpä henkilön iästä 


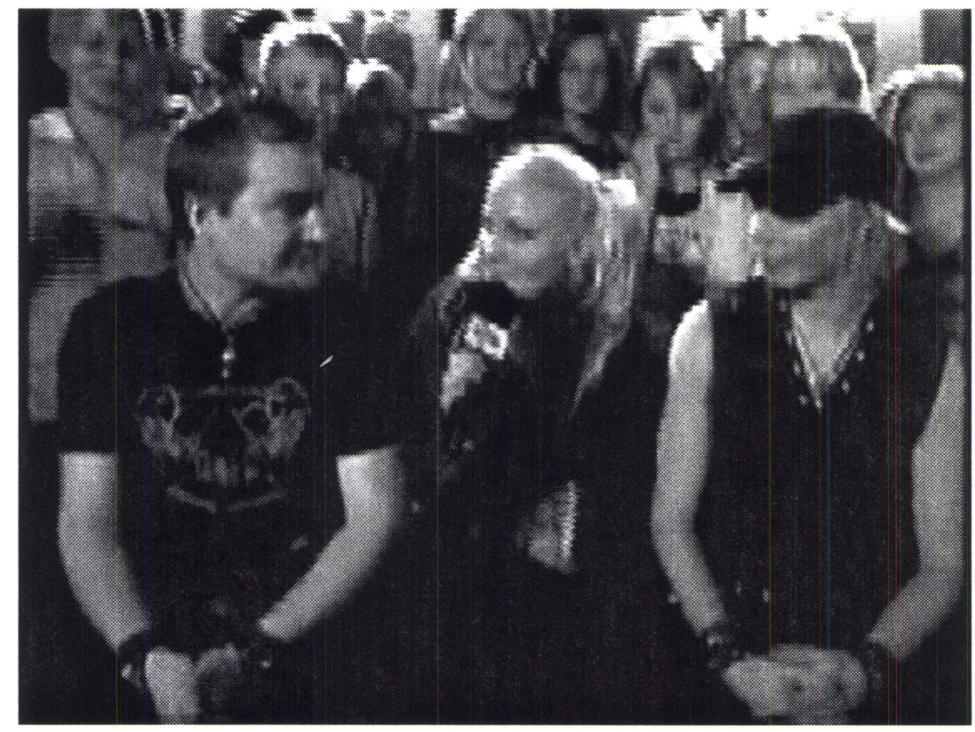

Kuva 8. Lovexin Jason (vas.) ja Theon Kids Top20 -juontaja Tea Hiillosteen haastattelussa 26.11.2006.

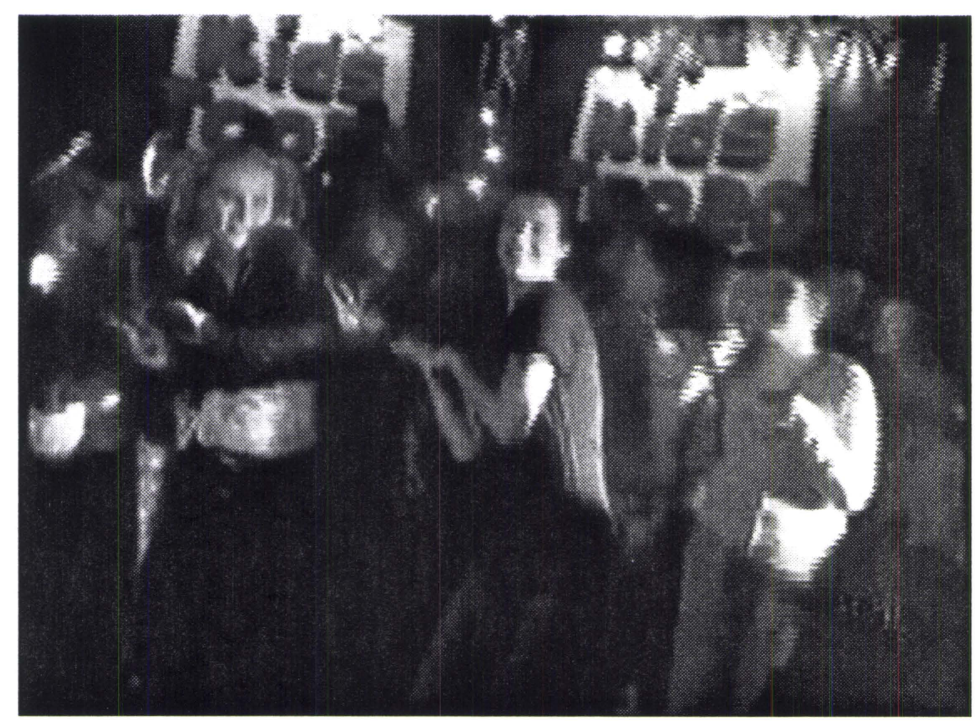

Kuva 9. Maija Vilkkumaa (kesk.) tanssimassa Hiillosteen ja lasten kanssa Kids Top20 -ohjelmassa 26.11.2006. 
riippumatta, kun taas saman yhteiskunnan täysivaltainen naispuolinen jäsen ei näin voi tai saa tehdä.

Videox-videoiden tanssikohtaukset ovat nekin sukupuolittuneita pääosin musiikin- ja tanssilajien konventionaalisten mallien mukaan. Esimerkiksi Kuningaskobrassa ja Jörö-Jukka-rockissa olevat 6-10 hengen ryhmäkoreografiat ovat vain tyttöjen toteuttamia. Meksikon pikajunassa sen sijaan asemalaiturilla esitettävän ryhmätanssin tusinasta jäsenestä puolet on poikia - ainoan yksintanssin esittää senkin poika. Burtia (1995) seuraten tämän koko Videox-tuotannossa ainutlaatuisen esityksen voi toki tulkita maskuliinista aktiivista toimijuutta korostavaksi tapahtumaksi, mutta yhtä olennaista on huomata kyseisen soolotanssin lajityypillinen muoto: arvatenkin konduktööriksi pukeutunut poika kiepahtaa käsilläseisonnan kautta lattialle pyörimään selällään eli hän esittää nimenomaan breakdance-liikkeitä (kuva 12), ja breakdance puolestaan (kuten hip hop yleisestikin) on leimallisesti miesesiintyjien hallitsemaa.

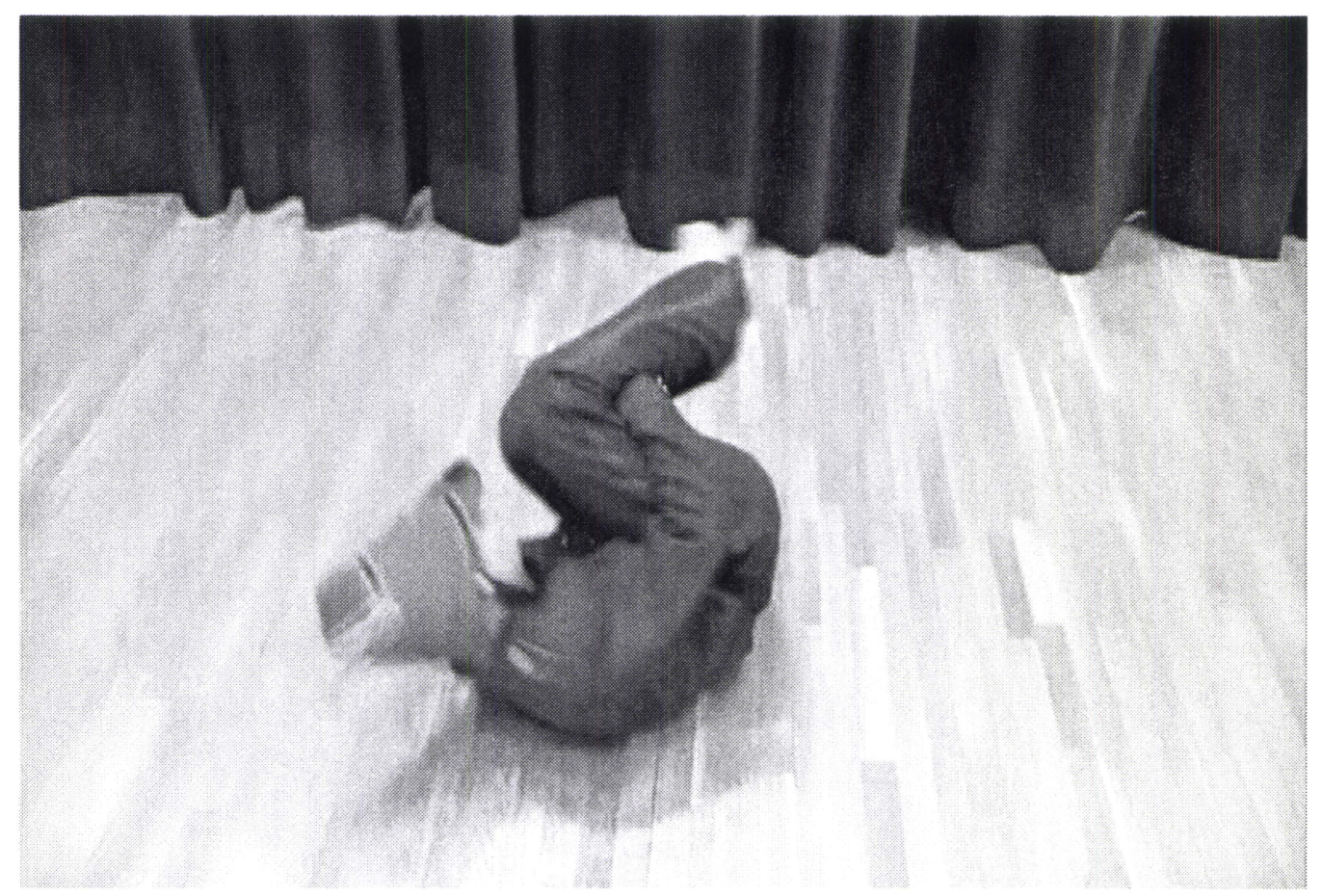

Kuva 12. Arvatenkin konduktööriksi pukeutunut b-boy Videox-videossa Meksikon pikajuna. 


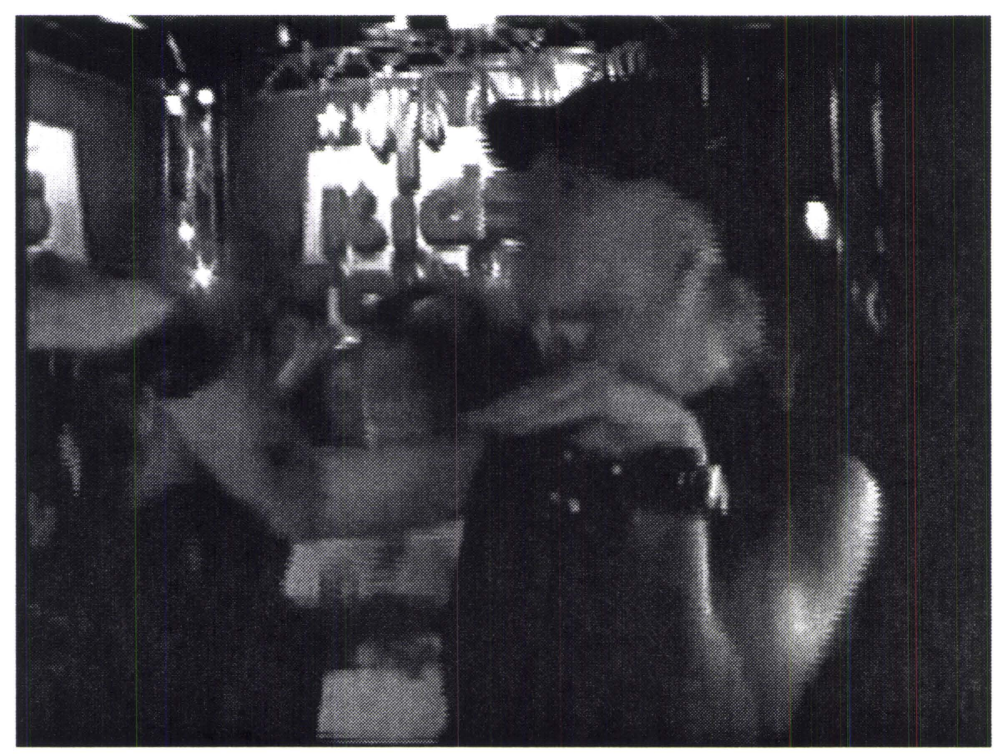

Kuva 10. Theonin "egyptiläinen" tanssi.

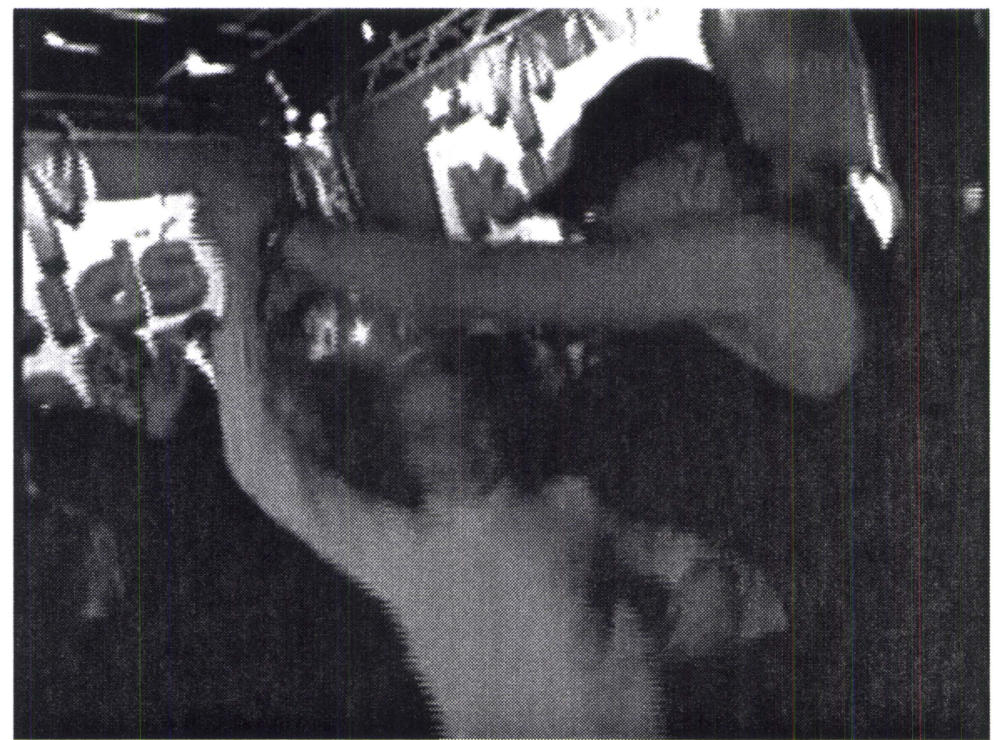

Kuva 11. Theon tanssii Kids Top20 -yleisöön kuuluvan tytön kanssa. 
Oman erityistapauksensa muodostavat vielä Videox-videoissa olevat kansanomaiset tai sellaisia muistuttavat tanssit. Mörri-Möykyssä 16 lasta tanssii ensin muun muassa kättelypiirissä kävellen ja myöhemmin parijonossa letkajenkan askelin, minkä jälkeen riveissä käännytään vastakkain ja muodostetaan käsillä katettu kuja, johon kahdeksan "peikkolasta" juoksee sisään. Intiaanin sotahuudossa taas tusina pientä "inkkaria" kiertää piirissä kiviröykkiöllä seisovan päällikkönsä ympäri. Näissä piiri- ja rivitansseissa sukupuoliroolit eivät ole järin korostuneet, vaan kaikilla tanssijoilla on samanlaiset liikesarjat. Intiaanin sotahuudossa piirin sukupuolijakauma on lisäksi tasainen, joskin päällikkö on patriarkaalisen stereotypian mukaan poika. Mörri-Möykyssä sen sijaan piiritanssijoista vain neljä on tyttöjä - mikä selittynee sillä, että myös kaikki peikkoja esittävät lapset ovat tyttöjä. Joka tapauksessa tanssin ja kansallisen identiteetin artikulaatiot vaikuttavat tarjoavan enemmän mahdollisuuksia myös poikien tanssille: toisin sanoen letkajenkan mielleyhtymät suomalaisuuteen sekä inkkarileikkien viittaukset epäilemättä täysin sepitteelliseen etniseen identiteettiin ovat kuitenkin aitouskäsitysten kyllästämiä siinä määrin, että homofobian epäilyttävästä peikkolapsesta ei tarvitse välittää.

\section{Lastenmusiikin ja -musiikkivideoiden muuttuvat muodot}

Suomen ajantasaista lainsäädännöstä ei löydy sanaa sensuuri, ja ainoa lakisääteinen kulttuurisen ilmaisun ennakkotarkastusvelvoite koskee kuvaohjelmien eli esimerkiksi elokuvien ja tietokonepelien tarkastusta. Velvoite puolestaan perustuu "lasten suojelemiseksi välttämättömiin rajoituksiin". Laissa eritellään myös erinäisiä tarkastuksesta vapautettuja kuvaohjelmia, kuten esimerkiksi "yksinomaan tai pääasiallisesti musiikkiesityksiä" ja "kaikenikäisille lapsille sopivia animaatio-, leikki-, askartelu- tai muita vastaavia esityksiä" sisältävät ohjelmat. (Kuvaohjelmalaki 775/2000, $2 \S, 4$ §.) Musiikkivideot eivät kuulu ennakkotarkastuksen piiriin, ja lakia täsmentävässä hallituksen esityksessä (HE 2/2000) ne määritelläänkin lain tarkoittamiksi "musiikkiesityksiä sisältäviksi tallenteiksi".

Kids Top20 -ohjelman musiikkivideot herättävät silti kysymyksen lastenkulttuurin ja -musiikin suhteesta aikuisten tai nuorison vastaaviin. Yhtäältä huomiota voi kiinnittää siihen, että videoissa ei juuri lapsiesiintyjiä näy, ellei sitten 17-vuotiaana Idols-kilpailussa toiseksi tullutta Anna Abreuta (s. 1990) lasketa sellaiseksi. Näin ollen videoiden tarjoamat suorat samastumismahdollisuudet ovat ikään kuin tule- 
vaisuuteen suuntautuneita. Kysymys siis kuuluu, oletetaanko tai peräti toivotaanko tämän päivän lasten toimivan vajaan kymmenen vuoden kuluttua videoilla esiintyvien hahmojen mukaan? 5.10.2008 esitetyn ohjelman listalla sijalla 12 ollut Pussycat Dolls -yhtyeen kappale ja video When I Grow Up liittyy jo nimellään tähän kysymykseen suoraan: millaisia samastumis- ja (tulevaisuuden) toimijuusmahdollisuuksia tällainen vähäpukeinen esiintyjäryhmä (kuva 13) tarjoaa erityisesti 12-13-vuotiaille tytöille? Toisin sanoen onko heidän esittämänsä musiikki ja muoti sitä, mihin tämän päivän esiteini-ikäisten lasten on tähdättävä mikäli mielivät menestyä musiikin alalla tai olla yleensäkin hyväksyttäviä toimijoita jälkiteollisessa mediayhteiskunnassa? Myös tässä yhteydessä on syytä arvioida nykypäivän yleiskulttuurin kaupallista perustaa: siinä missä Pussycat Dolls on levytys- ja kustannussopimustensa nojalla yhteistyössä lasvegaslaisen yökerhon ja Estee Lauder -kosmetiikkayrityksen kanssa, oli yhtye maaliskuussa 2009 myös yhdysvaltalaisen Nickelodeon-lastentelevisiokanavan Kids Choice Awards -palkintogaalan pääesiintyjä_(Serpick 2005; PCD 2009).

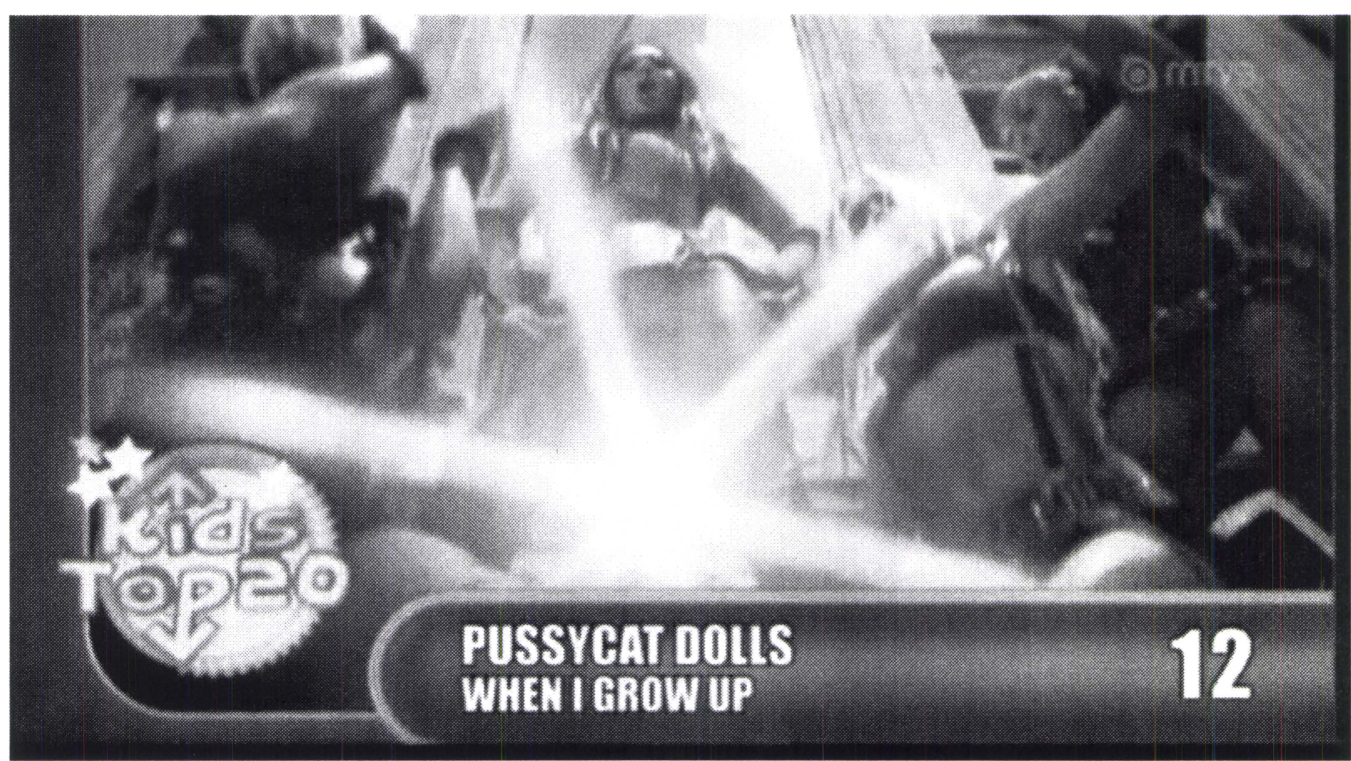

Kuva 13. Pussycat Dolls -yhtyeen When I Grow Up -video Kids Top20 -listalla 5.10.2008. 
Riippumatta meikkauksen aloitusiästä tai yökerhojen ikärajoista, Pussycat Dolls kaikesta päätellen on hyvinkin lavean ikähaitarin esiintyjäryhmä.

Vastaavasti Anna Abreun Vinegar-videossa nähtävät parikymppisten miesten paljaat ylävartalot (kuva 14), The Rasmus -yhtyeen Livin' in a World Without You -videossa olevat kohtaukset jaetussa vuoteessa (kuva 15), Cheekin Liekeissä-videon lähikuvat push-up-rintaliivejään peittelemättömistä naisista (kuva 16) sekä ABBAn Mamma Miassa olevat asusteet (kuva 17) herättävät kysymyksiä lapsille sopivista sisällöistä - viimeisimmät elleivät Agnetha Fältskogin kaula-aukon niin ainakin Björn Ulveausin kenkien turvallisuuden takia.

Leikkiä voi laskea lisäksi sillä, miten Iron Maidenin Run to the Hills -video on animoitujen rakettimoottoripyöräilijäzombielännenmieshahmojen avulla (kuva 18) mitä ilmeisimmin lapsiystävällisempi kuin esimerkiksi Music Television -rotaatiossa aikoinaan ollut "inkkarisotaa" mykkäelokuvien esitystavoilla mukaileva versio (kuva 19; ks. myös YouTube 2009a). Jälkimmäisessä kappaleen sanoituksessakin korostettu "valkoisen miehen" raakuus raiskauksineen ja tappamisineen saa astetta inhimillisemmän visuaalisen muodon, joskin erinäiset maskeeraus-, pyöräily ja peruukkipäisten valkonaamojen skalpeerauskohtaukset (kuva 19) viittaavat esitettyjen tapahtumien sepitteellisyyteen ja koomisuuteen. Kenties animoitu Pokémonestetiikka kaikessa totisuudessaan vetoaa 2000-luvun lapsiin kuitenkin tehokkaammin kuin lähes sadan vuoden takainen Chaplin-komiikka.

Run to the Hills on osuva esimerkki myös nimenomaisesti videoiden musiikillista ulottuvuutta ajatellen. Jos - ja kun - Kids Top20 nimetään lastenohjelmaksi, on vain loogista päätellä, että siinä esitettävä musiikki on lastenmusiikkia. Tällöin myös Run to the Hills edustaa tämän päivän lastenmusiikkia. Mutta kuten heavy metal -musiikkia tutkinut Robert Walser (1993: 137-147) osoittaa, tilanne oli kovin toinen kappaleen alkuperäisjulkaisun aikoihin vuonna 1982: tuolloin heavy metal yleisesti oli erityisesti Yhdysvalloissa vaikutusvaltaisten "huolestuneiden" vanhempien kritiikin kohteena. Usein huolen - ja muutamissa tapauksissa oikeuskäsittelyjen - aiheena olivat erityisesti väkivaltaisina ja saatanallisina pidetyt ja siten moraalittomiksi tulkitut sanat ja kuvat, mutta myös kovaa äänenvoimakkuutta, voimakasta lauluääntä, raskasta rumpupoljentoa ja säröisiä kitarasaundeja ajateltiin yhtä paheellisina. Iron Maiden erilaisia uskonnollisia ja mystisiä viittauksia hyödyntäneenä sekä oman Eddie-zombiehahmonsa luoneena yhtyeenä on saanut oman osansa heavy metal -paniikista, vaikka esimerkiksi Walser (1993: 151-153) pitää juuri Run to the Hills -kappaletta avoimesti yhteiskuntakriittisenä Pohjois-Amerikan alkupe- 

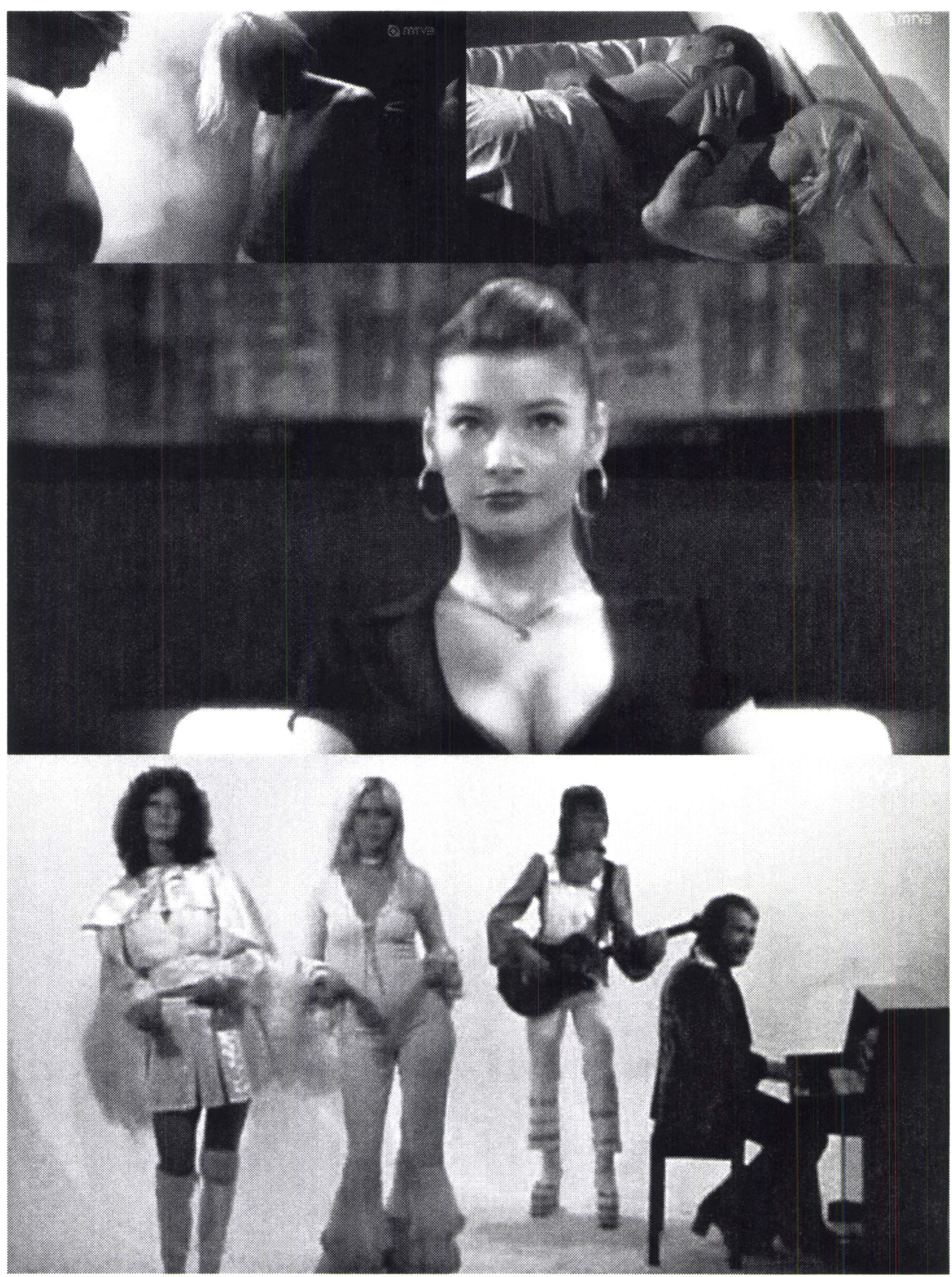

Kuvat 14-17. Arvatenkin "kaikenikäisille lapsille sopivia animaatio-, leikki-, askartelu- tai muita vastaavia esityksiä" Kids Top20:ssä 5.10.2008 esitetyissä Anna Abreun Vinegar-, The Rasmus -yhtyeen Livin' in a World Without You, Cheekin Liekeissä-, sekä ABBAn Mamma Mia -videoissa. 

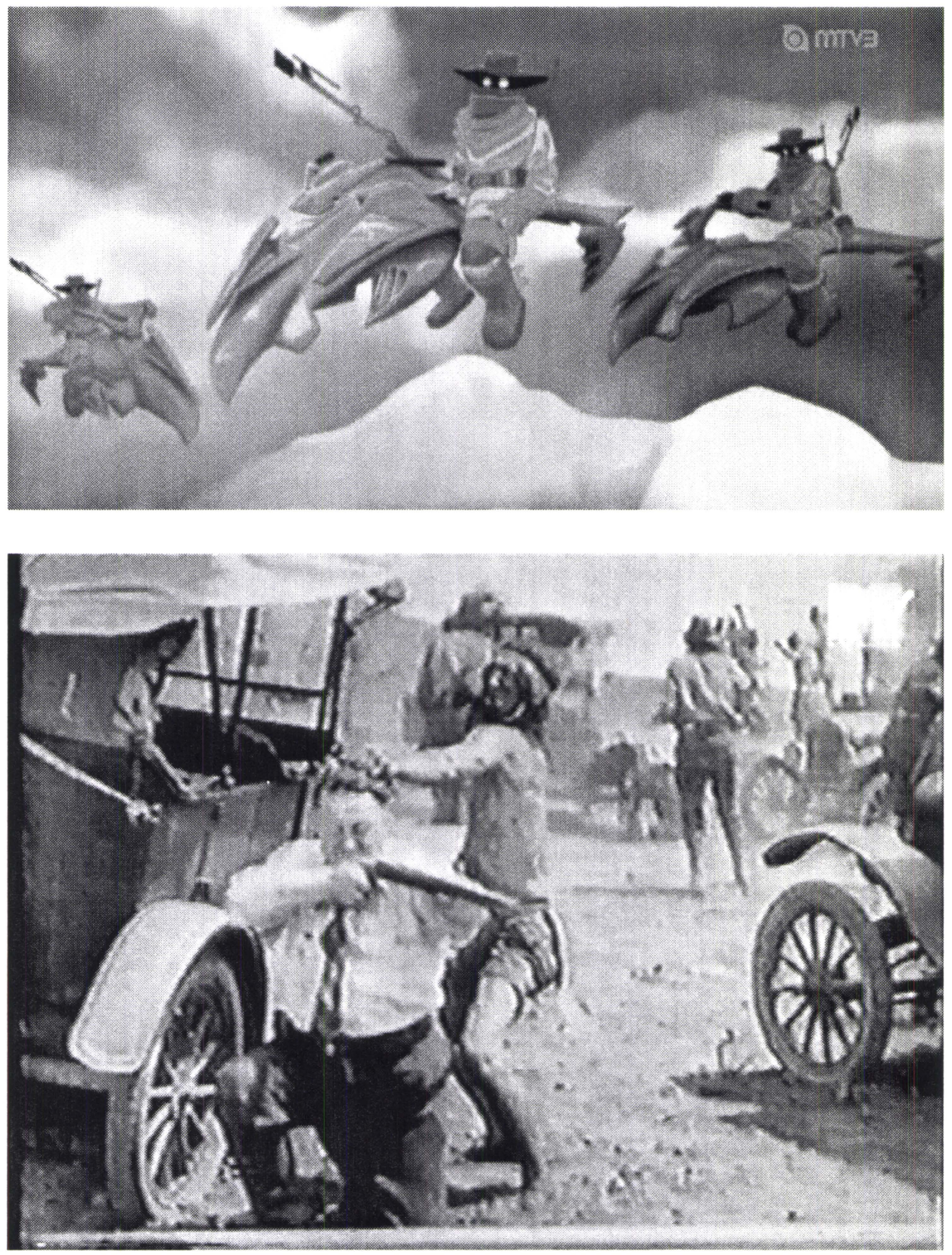

Kuvat 18 ja 19. Iron Maiden: Run to the Hills -kappaleen videot Kids Top 20:ssa 5.10.2008 ja MTV:n Alternative Nation -ohjelmassa joskus 1990-luvun puolivälissä. 
räisväestön kansanmurhaa käsittelevien sanojen takia. Lisäksi vaikka yhtyeen musiikki saattaa ensikuulemalta kuulostaa kaoottiselta odottamattomien sävellaji- ja tempovaihteluiden takia, perustuu tämä Walserin (1993: 157) mukaan "suunnittelun ja toteutuksen äärimmäiseen tarkkuuteen", joka osaltaan "manaa esiin monimuotoisia ja musertavia uhkaavia voimia, ja samalla tarjoaa ainoan eloonjäämisen toivon." Toisin sanoen heavy metal -musiikki ilmentää pikemminkin monimutkaisten ja vaikeidenkin asioiden viimekätistä hallintaa kuin hulluuteen ja itsemurhiin ajavia saatanallisia säkeitä ja sointuja.

Viikon 20/2009 Kids Top20 -listan (KT20 2009) perusteella 2000-luvun ensimmäisen vuosikymmenen lopun lastenmusiikin voi jakaa neljään pääkategoriaan:

1) kotimaisen rock/popin eri muodot (7: Laura Vanamo, Pete Parkkonen, Apulanta, Koop Arponen, Sturm und Drang, Haloo Helsinki, Monday - kaksi ensimmäistä ja neljäs näistä Idols-artisteja);

2) ulkomainen pop/r\&b (5: Lady GaGa, Hannah Montana, Alesha Dixon, Corbin Bleu, Enrique Iglesias);

3) koti- ja ulkomainen rap (3: Cheek, Akon, Flo Rida);

4) ulkomainen rock (3: AC/DC, Jonas Brothers, Mando Diao).

Hevi - tai tarkkaan ottaen "faaraohevi" (RA) - ja elektroninen tanssimusiikki (Waldo's People) sen sijaan olivat yksittäisten esiintyjien varassa, eikä listalla ollut sitä ensimmäistäkään nykyhetken suomalaisen musiikin vientitoivoa eli uudempia metallimusiikin suuntauksia edustavia artisteja. 40 äänestettävän kappaleen luettelosta löytyi yksi, kylläkin ulkomailta tilitettävillä tekijänoikeuskorvauksilla mitaten se suurin vientitoivo, The Rasmus -yhtye. (KT20 2009.)

Tuore kotimainen metalli ei kuitenkaan ole ollut tuntematon ilmiö Kids Top20 -listalla tai ohjelman perusteella kootuilla kokoelmalevyillä, joskin alkuperäisten esittäjien sijaan omia kaiketi lapsiystävällisempiä versioitaan esimerkiksi Teräsbetonin ja Lordin hiteistä ovat esittäneet sellaiset artistit kuin Pikku-Orava ja The Ratzz. Edellinen on "tributoinut" myös Irinan "radioystävällistä voimapoppia" (Ojala 2007), ja tällaista valtavirran populaarimusiikin laajentunutta markkinointia lapsiyleisölle voi pitää yhtä lailla pyrkimyksenä laajentaa musiikkiteollisuuden ansaintaketjuja kuin Pussycat Dollsin reissaamista kasinoilta lastentelevisiokanavien juhliin (ks. Serpick 2005). Niinpä esimerkiksi kotimaisen metallimusiikin vientipyrkimykset eivät selvästikään ole vain maantieteellisiä, vaan ne liittyvät myös ikäkategorioihin. Arviossaan Lordin Deadache-levystä Marko Säynekoski (2008) toteaakin, 
että "[o]n veikeätä, että Suomessa ja Ruotsissa Lordi lasketaan lastenmusiikiksi ja Saksassa maestro poseeraa vähäpukeisten neitojen rinnalla." Lisäksi jos - ja luultavimmin kun - Lordin videoita esitettiin Kids Top20:ssa, ne rinnastuvat vähintään yhtä veikeästi ohjelmaa molemmin puolin ympäröineisiin lelumainoksiin (joista tietysti yksi on voinut olla Mr. Lordi -figuurin mainos). Ilmiö on malliesimerkki musiikki- ja yleisemmänkin mediateollisuuden synergiasta, jolla tarkoitetaan erityisesti niin sanottua ristiinmarkkinointia (eli elokuvilla tai nukeilla myydään musiikkia ja päinvastoin), mutta joka on syytä ymmärtää moniulotteisempana suuryritysten ja mediakonglomeraattien toimintaperiaatteena immateriaalioikeuksien hyödyntämiseksi mahdollisimman tehokkaasti, taloudellisten riskien hajauttamiseksi sekä työvoimaresurssien hallitsemiseksi (Smith 1998: 188-191; ks. myös Denisoff \& Plasketes 1990; Wall 2003: 110).

Listalla on ollut joka tapauksessa RAn lisäksi toinenkin yhtye, jonka esittäjät ovat jokseenkin samanikäisiä kuin ohjelman studioyleisö. Siscott-niminen kahden tytön lauluduo valtasi peräti ykkössijan omalla Harry Potter -kappaleellaan, jonka todetaan yhtyeen verkkosivuilla olevan tyyliltään "lastenpoppia" (Siscott 2009). Kappaleen äänitteen perusteella lastenpopin ytimessä on sähkökitaran, sähköbasson, pianon ja rumpujen muodostama kvartetti. Tyylilajin laulu puolestaan on äänenvoimakkuuden ja -muodostuksen vaihteluiltaan hyvin vähäistä ja duettoesityksestä huolimatta yksiäänistä. Miksauksessa laulu on selvästi voimakkaampana kuin säestävät soittimet, joskin alun introssa ja keskivaiheen väliosassa (joka on identtinen intron kanssa) sähkökitaran kompressoitu saundi korostuu. Kappaleen sointupohja rakentuu tonaalisen harmonian varaan (mm. F-C7-F-Bb-F-C7-F), ja melodia nojaa paljolti samojen sävelten toistoon ja asteittaiseen äänenkuljetukseen ajoittaisine terssi- ja kvarttihyppyineen (esim. kertosäkeistön alku pienen oktaavialan mukaan merkittynä: c-c-f-f-f-f-f-f-e-d-e-g). Kromaattisia sivusäveliä ei ole. Kappaleen tahtilaji puolestaan on $12 / 8$ ja se soitetaan nopeana kolmijakoisena "shufflena".

Instrumentaation, saundien, harmonian, melodian ja rytmiikan osalta Siscott-yhtyeen Harry Potter ei ratkaisevasti eroa populaarimusiikin valtavirrasta, joskin tyyliä voinee halutessaan nimittää vanhahtavaksi: 1950- ja 1960-luvulla tällaiset keinovarat olivat hyvinkin suosittuja ja ajoittain niitä saatettiin pitää jopa rajoja rikkovina. Se, mikä tekee kappaleesta lastenmusiikkia, vaikuttaisi liittyvän miksaukseen, laulutapaan ja itse esittäjiin. On kuitenkin hyvä huomata, että tällaiset musiikintekemisen käytännöt eivät ole mitenkään erityisen uusia. Ruotsalaista vuosina 1904-1980 äänitteillä julkaistua lastenmusiikkia tutkineen Kajsa Paulssonin (2006: 240, 252-253) 
mukaan lastenmusiikin muutokset seuraavat monilta osin "aikuismusiikissa" ja varsinkin populaarimusiikissa tapahtuvia muutoksia, ja hän epäileekin, että muutosten "itämisaika" on jatkuvasti vain lyhentynyt vuosien varrella. Vaikka lastenmusiikkia voisikin luonnehtia yleisesti tyyliltään "yksinkertaiseksi ja selkeäksi", vaikuttaa siltä, että musiikillisia ratkaisuja keskeisimpiä tekijöitä ovat (lapsi)esiintyjät, sanoitukset ja (oletettu) kohdeyleisö. Paulssonkin (2006: 254) viittaa käsitteellisiin rajanvetoihin lasten-, nuoriso- ja aikuismusiikin välillä, minkä puolestaan voi ajatella olevan nimenomaan yleisöjen segmentoimista eli ennen muuta musiikin markkinointia ja myyntiä palveleva ideologinen rakennelma (Wall 2003: 110). Kategorioiden välisten rajojen hämärtymisestä kielivät kuitenkin myös Tean C'mon C'mon -videosta YouTubessa (2009b) esitetyt kommentit: "ei vittu mitä paskaa. anteeks nyt mut tea tekee jotain 7-vuotiaiden musaa" (nimimerkki ALESIINah) ja "Jotai lasten abc-musaa "me,te,he ;D;D;D;D" (nimimerkki I3ttor). Varsinkaan ensimmäisen kommentin pejoratiivista sävyä ei voine kiistää, mutta olennaista onkin, että lastenmusiikista rakentuu tällaisen kielenkäytön myötä alempiarvoinen valtavirran populaarimusiikin kategoria. Videox-videoissa sen sijaan diskurssin logiikka on ikään kuin päinvastainen, sillä populaarimusiikin valtasuuntauksia käytetään ajan patinan karsimiseen: "Videoiden taustalla soivat uudet versiot vanhoista tutuista lauluista. Saku Sammakko on saanut uuden hiphop-biitin ja Kuningaskobrassa on mukana itämaisia mausteita. Mukana on myös rämeää rockia!" (YLE 2005).

\section{Lopuksi}

Australialainen sosiologi Beryl Langer (2004: 252-253) esittää, että nykyhetken "lastenkulttuuriteollisuudessa" aikaisempi "pyhän lapsen" ja "maallisten markkinoiden" välinen jännite on menettänyt merkityksensä. Tämän sijaan 2000-luvun alun jälkiteollinen lastenkulttuuri pohjautuu hänen mukaansa "hyväksikäytön ja haltioitumisen ambivalenttiin yhdistelmään". Siinä määrin missä nuoriso- tai aikuisvideot liudentuvat lasten musiikkivideoiksi Kids Top20:ssa, Langerin otaksuma on osuva, ja "2000-luvun alussa ne 'synkeät salaisuudet', joilta lasten viattomuutta on suojeltava, eivät ole seksuaalisia, vaan teollisia" (Langer 2004: 264). Yhtälöön voi lisätä vielä väkivallan ja kauhun: Lordin asema maan johtavana lastenmusiikkiorkesterina sai kovan kolauksen 23.4.2009 Espoon Barona-areenalla, sillä yhtyeen esitykseen kuuluneet tappo- ja aivojensyöntikohtaukset saivat paikalla olleet lapset ja monet van- 
hemmat kauhistumaan ja poistumaan paikalta. Seuraavana päivänä Ilta-Sanomain verkkosivuilla avattiin verkkoäänestys, jossa kysyttiin "[o]nko Lordi lapsille sopivaa katseltavaa ja kuunneltavaa", ja neljän päivän kuluessa 85 prosenttia yli 30000 vastaajasta oli valinnut ei-vaihtoehdon (IS 2009).

Lasten ja vanhempien maininta johtaa suoraan kysymyksiin mediakasvatuksesta ja -lukutaidosta. Ilta-Sanomissa itse asiassa huomautettiin siitä, että osaltaan Lordin konsertin aiheuttama järkytys saattoi johtua vanhempien kyvyttömyydestä arvioida esityksen sisältöä esimerkiksi sen alkamisajankohdan (klo 22) perusteella (Leinonen 2009). Toisaalta The Voicen aihetta koskevalla verkkokeskustelupalstalla (Voice 2009) perättiin myös ennakkovaroituksia mahdollisesti järkyttävistä väliesityksistä. Myös julkisuuden tavoitteluun liittyvät päämäärät nostettiin esiin: "Hyvä vaan, Lordillekin vaihteeksi huomiota" (nimimerkki Soole Miio). Konserttiesitykset ovat toki oma esittämisen muotonsa ja voivat esimerkiksi ikärajan turvin tarjota mahdollisuuksia hyvinkin provokatiiviseen ilmaisuun, kun taas musiikkivideoilla on omat rajoitteensa, jotka liittyvät ajatukseen mediaystävällisyydestä sekä parhaan katseluajan tai "hevirotaation" eli runsaan päivittäisen toiston tavoitteluun. Lasten ja audiovisuaalisen media suhteesta on myös koko joukko erityisesti erilaisten yleishyödyllisten järjestöjen antamia suosituksia: esimerkiksi Yhdysvaltain lastenlääkäriakatemian viestintätyöryhmä esitti vuonna 1996 seuraavia toimenpiteitä musiikkivideoita kohtaan (AAP 1996: 1220):

1) sääntely vanhempien taholta,

2) vanhempien medialukutaidon kehittäminen,

3) tuottajien hienotunteisuus ja itsehillintä,

4) positiivisia aiheita käsittelevien videoiden tuotanto, sekä

5) videoiden vaikutuksia koskevan tutkimuksen kehittäminen.

Suositusten taustalla on ajatus siitä, että musiikkivideot sisältävät "ylenpalttisesti seksismiä, väkivaltaa, huumausaineiden käyttöä, itsemurhia sekä epäsoveliasta seksuaalista käytöstä" (AAP 1996: 1220). Suositukset käyvätkin todistusaineistona siitä, että ylikansallisessa musiikkiliiketoiminnassa erilaiset transgressiot ovat omiaan herättämään kiinnostusta ja keskustelua, oli se sitten moralisoivaa tai ei. Myös sukupolvi-ja ikäkysymys nousee esiin kiintoisalla tavalla, sillä kaikesta oletettavasta hyväntahtoisuudesta huolimatta AAP:n ohjeistus ei koske lasten itsensä toimintaa lainkaan. Kaikesta päätellen esimerkiksi lasten medialukutaidon kehittämistä ei ole pidetty asiaan kuuluvana. 


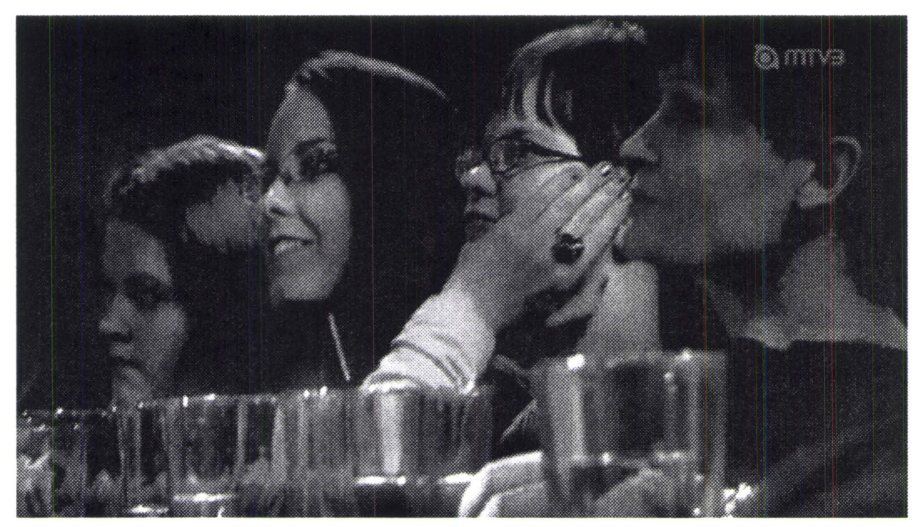

Kuva 20. Eturivin naisyleisöä Giant Leap -yhtyeen Remember-videon konserttikohtauksessa.

Vastapainona mediakasvatuksen lähtökohtia voikin punnita ajattelemalla lapsia Mitchellin ja Reid-Walshin (2002: 2-3) lailla asiantuntijoina. Tämän pohjalta voi esimerkiksi kysyä, eikö Kids Top20:ssa ja muissa vastaavissa ohjelmissa olisi mahdollista keskustella lapsiyleisön kanssa videoiden paljaasta pinnasta, väkivaltaisista eleistä ja aiheista, päihteiden käytöstä ja kirosanoista: mikä estää Maija Vilkkumaata kysymästä yleisöltä omien kouluaikojensa lempiaineen sijaan vaikkapa sitä, miten yleisön jäsenet tulkitsevat hänen Hei tie -kappaleessaan olevat sanat "kodissa jossakin ne soittivat jo poliisin ja se yksi paskiainen katuu mutta anteeksi ei saa"?

Ei käy kuitenkaan kiistäminen, etteikö tiedostavampaa keskustelua voisi käydä lasten kanssa myös Kids Top20 -ohjelman kaltaisessa formaattituotannossa. 26.11.2006 esitetyssä jaksossa Lovex-yhtyeen laulusolisti Theon kertoo olleensa "enemmänkin huolestunut" nuorten mielenterveydestä ja toteaa Bullet for the Pain -kappaleesta, että "itsemurha mikä on sit tietysti traagisin tapaus mitä siitä voi sattua niin tää biisi nyt sitte niinku vastustaa niitä ja kertoo faktoja että kuinka yleistä se Suomessa onkaan." Aiheen painavuudesta huolimatta tai ehkä pikemminkin sen takia voi kuitenkin kysyä, liekö alaluokkalainen studioyleisö juuri otollisin kohde: esimerkiksi Tilastokeskuksen mukaan vuosina 2005-2007 alle 15-vuotiaita itsemurhan tehneitä oli kaiken kaikkiaan yhdeksän eli 0,3 \% kaikista itsemurhan tehneistä (3051 henkilöä; TK 2009). Lisäksi Theonin itsemurhaa vastustavista kommenteista 
on huomattava, että hän antaa ne vastauksena Tean - eikä esimerkiksi studioyleisön - kysymykseen "aika koskettavan ja kantaaottavan" kappaleen taustoista. Pidemmälle lasten oma-aloitteellisuutta korostavassa toiminnassa päästäneenkin esimerkiksi 15.3.2008 esitetyssä jaksossa, jossa yleisön edustaja Sara kysyy Giant Leap -yhtyeen laulaja-kitaristilta Sebastian Rejmanilta ja kosketinsoittaja-laulajalta Petri Somerilta yhtyeen nimen merkitystä ja valintaperusteita, lempiruokaa ja -kukkaa sekä sitä, ovatko he huolissaan ilmastonmuutoksesta. Hän ei kuitenkaan kysy, miksi yhtyeen Remember-videolla konserttikohtauksen eturivin yleisö koostuu pari-kolmekymppisistä naisista olut- tai siiderituoppeineen (kuva 20) eikä esimerkiksi viidesluokkalaisista pillimehuineen - tai miksi yhtyeen kaikki jäsenet ovat miehiä.

Ylenpalttinen kriittisyys ja reflektio voi toki helposti karsia sitä iloa ja mielihyvää, jota tietyn artistin "fanittaminen" tuottaa myös esiteini-ikäisille ihmisille. Lisäksi kriittisen mediakasvatuksen piirissä korostettu "kriittinen keskustelu, väittely ja analyysi" (Kellner \& Share 2005: 373) voi johtaa tilanteeseen, jossa representaatiot ja niiden tuotantotaustat ovat toissijaisia analyysitaitojen harjoittelulle. Riskinä on myös kriittisen mediakasvatuksen itsensä muuttuminen markkinavoimia palvelevaksi uusliberalistiseksi "kivaksi puuhasteluksi", jonka päämääränä on opetella nopean yksilöllisen rikastumisen keinoja yhteiskunnallisen tiedostamisen sijaan (Herkman 2007: 220-222).

Voi olla, että lapsille suunnatuissa televisio-ohjelmissa ei useinkaan pyritä varsinaiseen mediakasvatukseen tai musiikin merkitysten pohdintaan, vaan pikemminkin tarjoamaan mahdollisuuksia tutustua erilaisiin musiikillisiin käytäntöihin ja siten myös lisäämään lasten omia musiikintekemisen vaihtoehtoja (Buller 2003). Silti mikäli nykypäivän lastenmusiikki on yhä enenevässä määrin samaa kuin täysiikäistenkin, vaihtoehtojen määrä tuskin kasvaa. Standardituotanto ja standardiyleisöt palvelevat tietysti ylikansallisen musiikkiteollisuuden intressejä, mutta samalla ne tarjoavat perustan yksipuolisille, stereotyyppisille audiovisuaalisille representaatioille, liittyivätpä nämä sitten ihmisryhmien väliseen identiteettipolitiikkaan tai musiikin harjoittamisen käytäntöihin. Olennaista on myös se, että tällaisessa tilanteessa lasten oma ääni ei edelleenkään kuulu. 
Artikkeli on osa Suomen Akatemian rahoittamaa "Populaarimusiikki jälkikoloniaalisessa Suomessa" -tutkimushanketta. Artikkeliin liittyvää tutkimustyötä on rahoittanut myös Jenny ja Antti Wihurin rahasto.

\section{Lähteet}

AAP = American Academy of Pediatrics (1996) "Impact of Music Lyrics and Music Videos on Children and Youth". Pediatrics 98:6, ss. 1219-1221.

Bayton, Mavis (1997) "Women and the electric guitar". Sexing the Groove. Popular Music and Gender. Toim. Sheila Whiteley. London \& New York: Routledge. Ss. 37-49.

Beebe, Roger \& Middleton, Jason (toim.) (2007) Medium Cool. Music Videos from Soundies to Cellphones. Durham \& London: Duke University Press.

Buckland, Theresa (1998) "Dance and Music Video. Some Preliminary Observations". The Routledge Dance Studies Reader. Toim. Alexandra Carter. London \& New York: Routledge. Ss. 278-287.

Bull, Michael \& Back, Les (2003) "Introduction: Into Sound". The Auditory Culture Reader. Toim. Michael Bull \& Les Back. Oxford \& New York: Berg. Ss. 1-18.

Buller, Jennifer (2003) "Music in Children's Television". Canadian Music Educator 44:3, ss. 32-36.

Carson, Mina \& Lewis, Tisa \& Shaw, Susan M. (2004) Girls Rock! Fifty Years of Women Making Music. With a Foreword by Jennifer Baumgardner and Amy Richards. Lexington: The University Press of Kentucky.

Covach, John (2007) What's That Sound? An Introduction to Rock and Its History. New York: W.W. Norton.

Denisoff, R.Serge \& Plasketes, George (1990) "Synergy in 1980s Film and Music: Formula for Success or Industry Mythology?" Film History: An International Journal 4:3, ss. 257-276.

Doubleday, Veronica (2008) "Sounds of Power: An Overview of Musical Instruments and Gender". Ethnomusicology Forum 17:1, ss. 3-39.

Foucault, Michel (1998) Seksuaalisuuden historia: tiedontahto, nautintojen käyttö, huoli itsestä. Suom. Kaisa Sivenius. 2. painos. Helsinki: Gaudeamus.

Garofalo, Reebee (1997) Rockin' Out. Popular Music in the USA. Boston: Allyn \& Bacon.

Goodwin, Andrew (1992) Dancing in the Distraction Factory. Music Television and Popular Culture. Minneapolis: University of Minneapolis Press.

HE (2000)"HE 2. Hallituksen esitys Eduskunnalle laiksi kuvaohjelmien tarkastamisesta sekä eräiksi siihen liittyviksi laeiksi". Www-sivustolla Eduskunta - valtiopäiväasiakirjat, http://217.71.145.20/ TRIPviewer/show.asp?tunniste=HE+2/2000\&base=erhe\&palvelin=www.eduskunta.fi\&f $=W P$ (luettu 1.9.2009).

Herkman, Juha (2007) Kriittinen mediakasvatus. Tampere: Vastapaino.

IS (2009) "Lordi söi lapsia lavalla - lapsiyleisö itki!" Www-sivustolla Ilta-Sanomat. Viihdeuutiset, http://www.iltasanomat.fi/viihde/uutinen.asp?id=1678124 (luettu 28.4.2009).

Kaplan, E. Ann (1987) Rocking Around the Clock. Music Television, Postmodernism, and Consumer Culture. New York \& London: Routledge.

Kellner, Douglas \& Share, Jeff (2005) "Toward Critical Media Literacy". Discourse 26:3, ss. 369386.

King, Anthony (2009) "Overcoming Structure and Agency. Talcott Parsons, Ludwig Wittgenstein and the Theory of Social Action". Journal of Classical Sociology 9:2, ss. 260-288. 
KT20 (2009) Kids Top 20 - Juniori.fi, http://www.juniori.fi/kidstop20/ (luettu 15.5.2009).

Kuvaohjelmalaki (2000) "Laki kuvaohjelmien tarkastamisesta 25.8.2000/775". Www-sivustolla Finlex, www.finlex.fi (luettu 8.4.2009).

Kärjä, Antti-Ville (2008) "Suomalaisissa musiikkivideoissa mies ei tanssi - Antti Tuisku tanssii". Teoksessa Kai Åberg \& Lotta Skaffari (toim.) Moniääninen mies. Maskuliinisuuden kulttuurinen rakentuminen musiikissa. Nykykulttuurin tutkimuskeskuksen julkaisuja 95. Suomen Etnomusikologisen Seuran julkaisuja 17. Jyväskylä: Jyväskylän yliopisto. Ss. 191-226..

Langer, Beryl (2004) "The Business of Branded Enchantment". Journal of Consumer Culture 4:2, ss. 251-277.

Lehtonen, Mikko (2002) "Surmaako kuva sanan? Multimodaalisuuden haasteet tekstintutkimukselle". Kieli yhteiskunnassa-yhteiskunta kielessä. AFinLAn vuosikirja 2002. Toim. A. Mauranen \& L. Tiittula. Jyväskylä: Suomen soveltavan kielitieteen yhdistyksen julkaisuja no. 60. Ss. 45-60.

Leinonen, Pauliina (2009) "Lapset järkyttyivät Lordin Show'sta". Ilta-Sanomat 25.4.2009, s. 7.

Lovex (2009) Lovex, http://lovex.fi/ (luettu 6.4.2009).

McClary, Susan (2003) "Bessie Smith: 'Thinking Blues'”. The Auditory Culture Reader. Toim. Michael Bull E Les Back. Oxford \& New York: Berg. Ss. 427-434.

Mitchell, Claudia \& Reid-Walsh, Jacqueline (2002) Researching Children's Popular Culture. London \& New York: Routledge.

MTV3 (2009) "K-70". MTV3.fi, http://www.mtv3.fi/ohjelmat/sivusto.shtml/viihde/k70/taustaa?596763 (luettu 1.9.2009).

Ojala, Pertti (2007) "Irina - Liiba Laaba". Soundi 4/2007, http://www.soundi.fi/arvostelut?nid=1717 (luettu 14.4.2009).

Paulsson, Kajsa (2006) "Nu ska du få höra. Svenska musikfonogram för barn 1904-1980". Skrifter från Institutionen för musikvetenskap, Göteborgs universitet nr 81. Göteborg: Göteborgs universitet.

PCD (2009) "Doll Domination/News/Don't Miss The Pussycat Dolls Performance on the Kids Choice Awards!" Www-sivustolla Pussycat Dolls, http://www.pcdmusic.com/News/Dont-Miss-ThePussycat-Dolls-Performance-on-the-Kids-Choice-Awards/0FCFEFFFF0000144F001600B3DE78 (luettu 8.4.2009).

Poliisi (2009) Virkavaatteet, http://www.poliisi.fi/poliisi/home.nsf/pages/1E989E36D88C94 C6C225 6B870046420D?opendocument (luettu 3.4.2009).

RA (2009) RA, http://the-ra.fi/ (luettu 9.4.2009).

Rossi, Leena-Maija \& Seppä, Anita (2007; toim.) Tarkemmin katsoen. Visuaalisen kulttuurin lukukirja. Helsinki: Gaudeamus.

Scott, Derek B. (2003) From the Erotic to the Demonic. On Critical Musicology. Oxford: Oxford Universtity Press.

Seppänen, Janne (2005) Visuaalinen kulttuuri. Teoriaa ja metodeja kuvien tulkitsijoille. Tampere: Vastapaino.

Serpick, Evan (2005) "Rock \& Roll: Music's New Deal - To Combat Sinking CD Sales, Labels Get into T-Shirts, Cosmetics and Even the Nightclub Business". Rolling Stone 986 (3.11.2005), s. 20.

Siscott (2009) SISCOTT, http://www.siscott.fi/siscott.php (luettu 9.4.2009).

Smith, Jeff (1998) The Sounds of Commerce. Marketing Popular Film Music. New York: Columbia University Press.

Straw, Will (2001) "Dance music". The Cambridge Companion to Pop and Rock. Toim. Simon Frith, Will Straw \& John Street. Cambridge: Cambridge University Press. Ss. 158-175.

Säynekoski, Marko (2008) "Lordi - Deadache". Soundi 10/2008, http://www.soundi.fi/ arvostelut?nid=8338 (luettu 14.4.2009).

TK (2008) "Itsemurhan tehneet iän ja sukupuolen mukaan 1921-2007". Www-sivustolla Tilastokeskuksen PX-Web-tietokannat, pxweb2.stat.fi (luettu 4.5.2009).

Vernallis, Carol (2004) Experiencing Music Video. Aesthetics and Cultural Context. New York: Columbia University Press. 
Voice (2009) "Vanhemmat veivät lapsensa pois Lordin esityksestä: Sairasta!" Www-sivustolla The Voice - Musiikkiuutiset, http://www.voice.fi/index.php?option=com_sbsarticle\&tmpl=blog\&cid $=3639 \&$ cat $=1$ (luettu 28.4.2009).

Waksman, Steve (1999) Instruments of Desire. The Electric Guitar and the Shaping of Musical Experience. Cambridge \& London: Harvard University Press.

Wall, Tim (2003) Studying Popular Music Culture. London: Arnold.

Walser, Robert (1993) Running with the Devil. Power, Gender, and Madness in Heavy Metal Music. Hanover \& London: Wesleyan University Press \& University Press of New England.

Whiteley, Sheila (2000) Women and Popular Music. Sexuality, Identity, and Subjectivity. London \& New York: Routledge.

Wikipedia (2009) Lovex, http://fi.wikipedia.org/wiki/Lovex (luettu 6.4.2009).

YLE (2005) Videox, http://www.yle.fi/videox/ (luettu 28.4.2009).

YouTube (2009a) Iron Maiden Run to the Hills, http://www.youtube.com/watch?v=0UAA0FjOfoQ (luettu 9.4.2009).

YouTube (2009b) Tea beat Remu: C'mon C'mon, http://www.youtube.com/watch?v=ACkaWE4hIu4 (luettu 28.4.2009). 